\title{
Legislative Frameworks Used to Foster Petroleum Development
}

William T. Onorato

The World Bank Legal Department February 1995 


\section{Summary findings}

The main purpose of a legislative framework for petroleum development is to provide the basic context for, and the rules governing, petroleum operations in the host country; to regulate them, as they are carried out by domestic, foreign, and international enterprises; and to define the principal adminisrative, economic, and fiscal guidelines for investment activity in the sector.

Experience shows that the cornerstone of effective petroleum legislative frameworks for exploration and production operations is a broad, generic, short but thorough petroleum law (not overdetailed), complemented by enabling regulations and one or several variants of a model contract. Such frameworks give both the host country and international oil company investors a clear legal and contractual context in which to negotiate mutually advantageous exploration and production arrangements that develop the host state's petroleum resources.

The fiscal and tax aspects of the framework may be detailed in the petroleum law or in a separate petroleuı. revenue code, either of which would complete the legislative package.

Onorato identifies and details the essential elements of such a framework - petroleum law, regulations, and model contracts - and explains how these three components relate to one another.

This paper - a product of the Legal Department - is part of a larger effort to disseminate the Bank's experience in successful legal reform in the sectors in which it has been involved. Copies of the paper are available free from the World Bank, 1818 H Street NW, Washington, DC 20433. Please contact William Onorato, principal counsel, energy and mining, room MC6-101, extension 81611 (62 pages). February 1995.

The Policy Research Working Paper Series disseminates the findings of work in progress to encourage the exchange of ideas about development issues. An objective of the series is to get the findings out quickly, even if the presentations are less than fully polished. The papers carny the names of the autbors and should be used and cited accordingly. The findings, interpretations, and conclusions are the authors" oum and should not be attributed to the World Bank, its Execunive Board of Directors, or any of its member countries. 


\section{Legal Department}

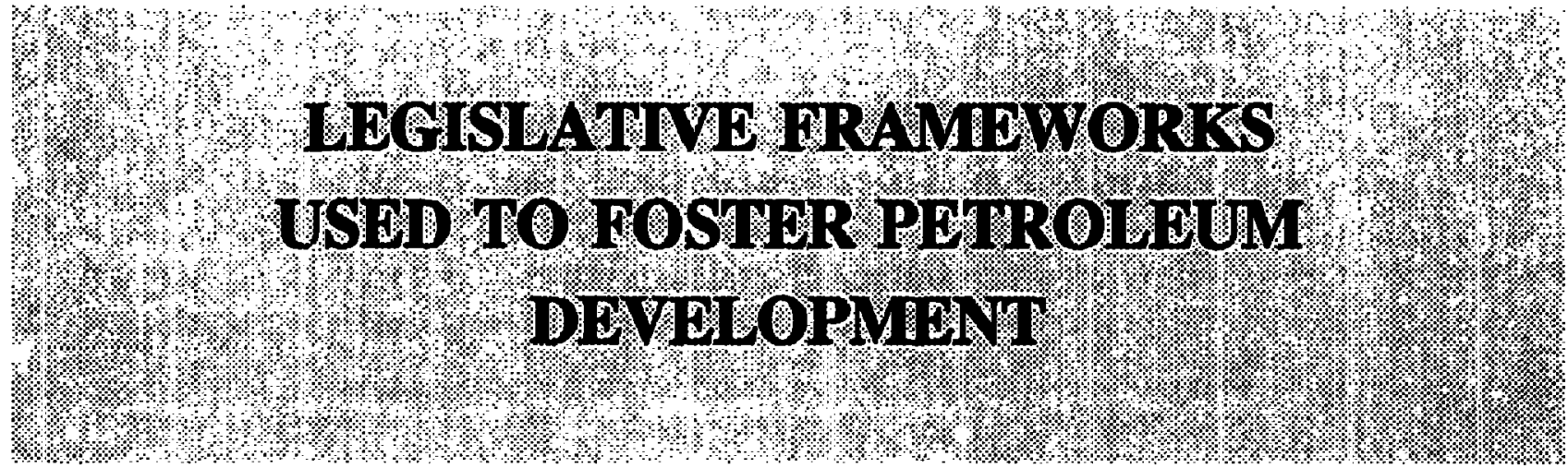

\section{William T. Onorato}

Identifies and explains the essential elements of legislative frameworks which have successfully attracted direct foreign investment into the sector and which have, consequently, fostered development of petroleum resources in host States. 


\section{PREFACE}

In any productive sector, the presence of an enabling legal and fiscal framework is an important catalyst for new investment and especially for the inflow of foreign investment. This is particularly the case in the petroleum sector where investments are typically of a long-term and high risk nature. Consistent with its development mandate, the World Bank has over the years played an important role in assisting its borrowing members in introducing legislative reforms which the members felt were needed and for which they sought the Bank's help. This has included various legislative initiatives with direct relevance to oil and gas.

Mr. Onorato's paper isentifies and explains the essential elements of legislative frameworks which have successfully fostered direct investment in the petroleum sector resulting in the development of petroleum resources in many countries. The paper is intended to be a useful tool for the Bank's country lawyers and task managers involved in petroleum sector projects with legal reform and technical assistance components. It deserves, however, to have a much broader audience in view of the practical and useful advice it contains.

As the Bank's lawyer most familiar with the Bank's experience in the field, Mr. Onorato is uniquely qualified to address this subject. His paper produces a concise overview of its topic. It draws on the considerable experience of Bank members and of the Bank itself in recent years in the field of legal reform in general and petroleum law in particular. Its conclusions must of course be adapted to the particular circumstances of each country and each project.

Other papers of this type may be usefully prepared by Bank lawyers to help disseminate the Bank's vast experience in successful legal reform in the sectors in which it has been involved.

Ibrahim F. I. Shihata

Senior Vice President and General Counsel

The World Bank 


\section{LIST OF ABBREVIATIONS}

\begin{tabular}{|c|c|}
\hline APT & Additional Profits Tax \\
\hline BOPD & Barrels of Oil Per Day \\
\hline $\mathbf{C A}$ & Competent Authority \\
\hline ESMAP & Energy Sector Management Assistance Program \\
\hline E\&P & Exploration and Production \\
\hline FSU & Former Soviet Union \\
\hline ICSID & International Center for the Settlement of Investment Disputes \\
\hline IFI & International Finance Institution \\
\hline IOC & International Oil Company \\
\hline $\mathbf{M}[\mathbf{A}] \mathbf{C}$ & Joint Management [Advisory] Committee \\
\hline $\mathbf{M C}(\mathbf{s})$ & Model Contract(s) \\
\hline MER & Maximum Efficient Rate [of Production] \\
\hline MWO & Minimum Work Obligation \\
\hline NOC & National Oil Company \\
\hline PA & Petroleum Agreement \\
\hline PEPP & Petroleum Exploration Promotion Project \\
\hline PL & Petroleum Law \\
\hline PRC & Petroleum Revenue Code \\
\hline PRT & Petroleum Revenue Tax \\
\hline PSC & Production Sharing Contract \\
\hline Regs & Regulations \\
\hline TA & Technical Assistance \\
\hline TOR & Terms of Reference \\
\hline
\end{tabular}




\section{CONTENTS}

I. Introduction and Summary $\ldots \ldots \ldots \ldots \ldots \ldots \ldots \ldots \ldots$

II. Essential Elements of a Petroleum Law ............... 5

(1) State Property in Petroleum $\ldots \ldots \ldots \ldots \ldots \ldots \ldots \ldots, \ldots$

(2) Competent Authority $\ldots \ldots \ldots \ldots \ldots \ldots \ldots \ldots \ldots 6$

(3) Petroleum Operations $\ldots \ldots \ldots \ldots \ldots \ldots \ldots \ldots \ldots$

(4) Petroleum Agreements $\ldots \ldots \ldots \ldots \ldots \ldots \ldots \ldots \ldots \ldots$

(5) Regulations $\ldots \ldots \ldots \ldots \ldots \ldots \ldots \ldots \ldots \ldots \ldots 11$

(G) Qualifications, Duties and Rights of Rightsholder or Contractor ........................12

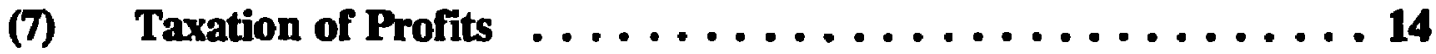

(8) Other Taxes, Duties and Exchange Controls ......... 18

(9) Fiscal Stabilization $\ldots \ldots \ldots \ldots \ldots \ldots \ldots \ldots \ldots \ldots \ldots \ldots$

(10) Environmental Protection and Safety $\ldots \ldots \ldots \ldots \ldots \ldots \ldots 21$

(11) Miscellaneous Provisions $\ldots \ldots \ldots \ldots \ldots \ldots \ldots \ldots \ldots \ldots \ldots$

(a) Definitions $\ldots \ldots \ldots \ldots \ldots \ldots \ldots \ldots \ldots \ldots \ldots \ldots \ldots$

(b) Natural Gas Development $\ldots \ldots \ldots \ldots \ldots \ldots \ldots 23$

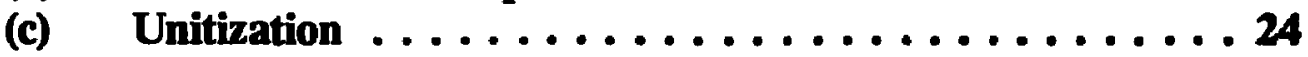

(d) Access to Land for Petroleum Operations ....... 25

(e) International Arbitration $\ldots \ldots \ldots \ldots \ldots \ldots 26$

(f) Affected Legislation; Relationship to Other Laws ..... 27

III. Regulations to a Petroleum Law $\ldots \ldots \ldots \ldots \ldots \ldots \ldots \ldots \ldots \ldots \ldots$

(1) Competent Authority $\ldots \ldots \ldots \ldots \ldots \ldots \ldots \ldots \ldots \ldots \ldots$

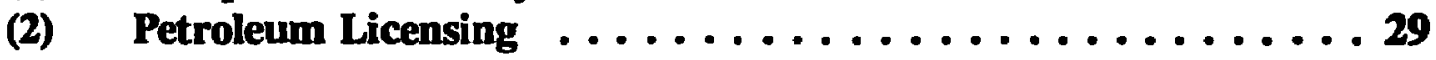

(a) Contract Area $\ldots \ldots \ldots \ldots \ldots \ldots \ldots \ldots \ldots \ldots \ldots$

(b) Bid Tenders $\ldots \ldots \ldots \ldots \ldots \ldots \ldots \ldots \ldots \ldots \ldots$

(c) Direct Negotiations $\ldots \ldots \ldots \ldots \ldots \ldots \ldots \ldots \ldots \ldots$

(3) Petroleum Operations $\ldots \ldots \ldots \ldots \ldots \ldots \ldots \ldots \ldots \ldots \ldots \ldots \ldots \ldots$

(4) Petroleum Agreements $\ldots \ldots \ldots \ldots \ldots \ldots \ldots \ldots \ldots \ldots \ldots$

(a) Contract phases; terms $\ldots \ldots \ldots \ldots \ldots \ldots \ldots \ldots . \ldots \ldots$

(b) Minimum work obligations $\ldots \ldots \ldots \ldots \ldots \ldots \ldots \ldots$

(c) Relinquishments $\ldots \ldots \ldots \ldots \ldots \ldots \ldots \ldots \ldots \ldots \ldots$

(5) Fiscal and Financial Regime $\ldots \ldots \ldots \ldots \ldots \ldots \ldots \ldots \ldots \ldots \ldots$

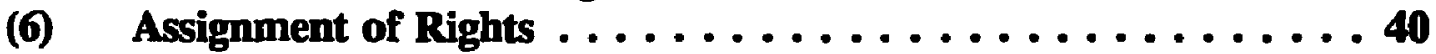

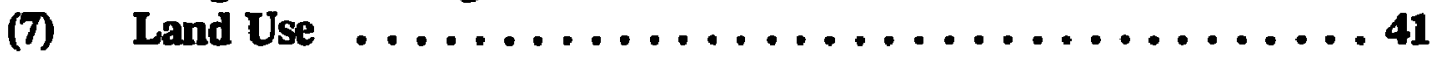

(8) Environmental Protection $\ldots \ldots \ldots \ldots \ldots \ldots \ldots \ldots \ldots, 41$

(9) Miscellaneous Provisions $\ldots \ldots \ldots \ldots \ldots \ldots \ldots \ldots, 42$

The author wishes to acknowledge the helpful comments made on initial drafts of this paper by Messrs. Ibrahim Shihata and Ian Newport. Their comments have been fully incorporated into the final version. The author also wishes to thank Mr. Mariadoss Paulraj for his excellent cooperation and assistance in the preparation of this paper. 
(a) Definitions ....................43

(b) Records and Reports .................43

(c) Accounts .....................4 43

(d) Production Rates . .................43

(e) Measurement of Petroleum .................44

(n) Confidentiality ...................44

(g) Indemnity ......................44

(b) Penalties $\ldots \ldots \ldots \ldots \ldots \ldots \ldots \ldots \ldots \ldots \ldots \ldots$

(10) Model Forms . . . . . . . . . . . . . . . . . . . . 44

IV. Model Contract(s) ...........................45

(1) Scope, Duration, and Grant of Rights ...........45

(a) Scope .......................46

(b) Periods, Phases and Terms .............. 47

(c) Grant of Rights ................. 47

(2) MWO, Work Program and Guarantees . . . . . . . . . 47

(3) Relinquishments ......................48

(4) Declaration of Commercial Discovery ... . . . . . . . . 49

(5) Joint Management [Advisory] Committee ... . . . . . . 49

(0) Cost Recovery, Expenses and Production Shares ........ 50

(7) Taxes and Duties $\ldots \ldots \ldots \ldots \ldots \ldots \ldots \ldots \ldots \ldots \ldots$

(8) Fees and Bonuses $\ldots \ldots \ldots \ldots \ldots \ldots \ldots \ldots \ldots \ldots$

(9) Protection of the Environment . . . . . . . . . . . . 53

(10) Supply of Domestic Market; Emergency Requisition . . . . . . 54

(11) Training of Host State Personnel .............. 55

(12) Other Standard Provisions . . . . . . . . . . . . . . 55

v. Conclusion $\ldots \ldots \ldots \ldots \ldots \ldots \ldots \ldots \ldots \ldots \ldots \ldots \ldots \ldots \ldots \ldots \ldots$

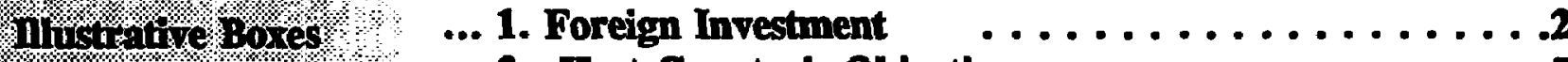

2. Host Country's Objectives $\ldots \ldots \ldots \ldots \ldots \ldots \ldots$

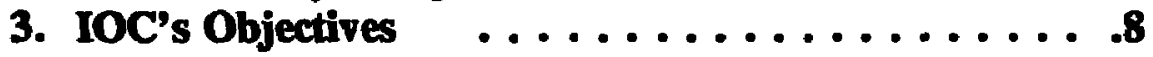

4. Exploration Period $\ldots \ldots \ldots \ldots \ldots \ldots$

5. License or Concession . . . . . . . . . . . .39

6. PA Variants $\ldots \ldots \ldots \ldots \ldots \ldots \ldots \ldots \ldots$

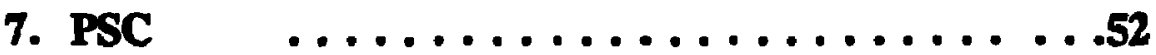

ANNEX . . TABLE OF BANK GROUP'S . . . . . . . . . . . . . . . .58 RELEVANT PETROLEUM SECTOR

LOANS, CREDITS, INVESTMENTS AND LEGAL TA (EFFECTIVE AND PROPOSED)

1980 - 1994 


\section{Legislative Frameworks}

\section{Used to Foster Petroleum Development}

\section{By William T. Onorato}

\section{Introduction and Summary}

In the course of my ten years as the Bank's legal adviser on petroleum matters, I have had the opportunity to advise on the creation of appropriate legislative frameworks aimed at fostering the development of petroleum resources in over forty member countries, worldwide'. This has been done principally through active participation in the legal reform and technical assistance (TA) components of petroleum exploration promotion projects (PEPPs), which, inter alia, support the development of enabling legislation to help Bank members with petroleum potential attract foreign direct investment and risk-capital into this critical sector of their economies. Most recently, under the Technical Cooperation Program for the former Soviet Union (FSU) and certain of its adhering Republics', such expert legal TA was provided to both the Republics of Russia and Kazakhstan. Its objective was to aid them in the development of acceptable, international-standard, legal, contractual and fiscal frameworks to encourage a quickening of the pace of petroleum

\footnotetext{
.BA, JD, Ph.D. (Cantab); Principal Counsel, Energy \& Mining, The World Bank; Adjunct Professor of Lav, Georgotoun Universily Law Center.

1. Principally in Sub-Saharan Afriea, Eastom Europe, Latin America and the Caribboan and several Aslan countules. In this regard, please see the Amnex to this paper detailing the Bank group's petroleum sector loans, credits, inveetments and legal TA activities botween 1980 and 1994.

${ }^{2}$. Technical Cooperation Agreement dated November 5, 1991, between the Bank and the USSR, to which the Ropubllce of Russia, Kazakhstan, the Kyrgyz Republic and Bolans adhored, pursuant to the terms of the Agreement.
} 
investment operations in their respective territories. This work is currently ongoing, as, also, is similar work in some of the other FSU Republics ${ }^{3}$ under traditional Bank lending arrangements. Thus, since 1980,

the Bank has financed PEPPs

Eost Country Perspective

and other forms of petroleum

sector legal reform and TA with

the consistent objective of acting

Importance of forden Invodiniant in the potroleum saclor:

- Increase petroleum respurces development and reserves

- Inerease necesis to moderin technolops

- Improve menogement's aldils and profit oxientation

- Inerenue finonclol resources for development

- Betrabllsh lonoterm relintonships with IOC.

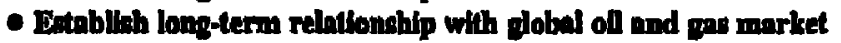

as a "catalyst" to mobilize the

inflow of foreign direct

investment into the developing

1. Foraign Investment

petroleum sectors of many of the Bank's borrowing members. ${ }^{4}$

In view, then, of this extensive experience in advising on the drafting of international-standard legal, contractual and fiscal frameworks for petroleum exploration and production (E\&P) operations in host countries, this paper seeks to draw together, discuss and critique the essential elements of such frameworks and to provide the author's recommendations on how best to structure them for the maximum attainment of their intended goals. The paper is intended to be a useful tool for the Bank's country lawyers and task managers involved in PEPPs or other petroleum sector projects with legal reform and TA components. While it clarifies and explains the principles and rationale for each essential element of such successful legislative frameworks, it must be emphasized that the

\footnotetext{
3. This Includes Azerbaljan, the Ukraine, Ueboklstan and, potentlally, Turkmeniatan.

4. Pusuant to tho Bank's "Guldalines for Petroleum Lending," Oins 3.82, November 28, 1984; Section III, Paragraph 16 thane of.
} 
actual drafting of such regimes is both complicated and highly specialized. In evnry case, this must be done by an experienced petroleum lawyer, thoroughly familiar with petroleum E\&P laws and contractual arrangements. For this reason, in part, this paper concentrates exclusively on providing an explanation of principles and elements of such model regimes, but, pointedly, offers no model language, clauses nor codes for their drafting. Indeed, Bank practice under both its projects and free-standing legal reform and TA in the petroleum sector requires that the actual drafting of laws and subsidiary instruments thereto - petroleum law (PL), regulations (Regs) and model contract (MC) - be done by extremely qualified petroleum lawyers (as such qualifications and requirements may be set out in the applicable terms of reference [TOR]), under the supervision of and subject to the recommendations and comments of, the Bank's specialized petroleum sector legal and technical staff experts.

Briefly, then, to summarize, the main purposes of a legislative framework is to provide the basic context for and the rules governing petroleum operations in the host country; to regulate them, as they are carried out by both domestic, foreign and international enterprises; and to define the principal administrative, economic and fiscal guidelines for investment activity in the sector. This paper identifies and details the essential elements of such a framework - PL, Regs and MC - and explains how these three components interrelate. Experience shows that the cornerstone of effective petroleum legislative frameworks for E\&P operations is a short but thorough, broad, generic PL, complemented by enabling Regs and one or several variants of a MC. Such frameworks provide both host country and international oil company (IOC) investor with a clear legal 
and contractual context within which to negotiate E\&P arrangements which are both mutually advantageous and developmental of the petroleum resources of the host State. In addition to the PL, Regs and MC(s), the fiscal and tax aspects of a complete petroleum legislative framework may either be detailed in the PL itself or separately set out in a companion petroleum revenue code (PRC), either of which would complete the legislative package. The core rationale behind the preference for a brief but thorough PL is that it is meant to cover all essential concepts necessarily required in a modern, enabling PL while not "setting them in concrete" through unnecessary over-detail. In this legislative scheme, such detail is reserved for subsidiary instruments such as the Regs and MC, which should not be required to be submitted to the legislature for amendment or change.

In addition, in this author's view, the best approach, whenever possible, is to package the legal, contractual and fiscal regime for petroleum operations into a selfcontained, coherent legislative framework, consistent, however, with both the overall legal system of the host State and with any applicable principles of international law. This is a great incentive to attracting significant foreign investment into the sector. Where an IOC is studying potential E\&P investments in candidate countries, given relatively equal petroleum-prospectivity, it will normally opt for the State which has such a coherent regime in place for petroleum operations. This, in preference to "piecing together" the legislative framework from provisions in both the PL and other necessarily related and relevant laws, such as those on foreign investment, taxation, land use, environment and the like. 


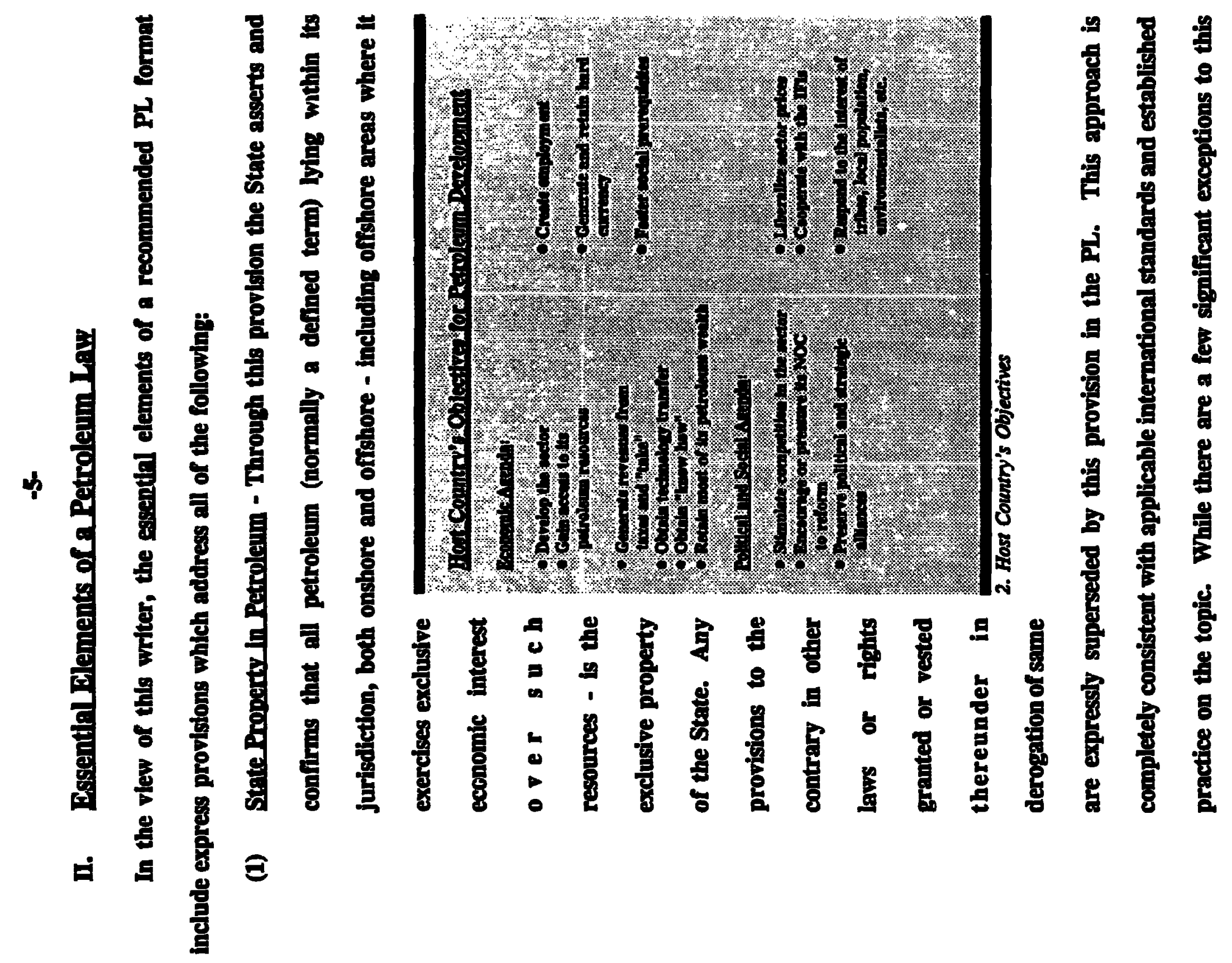


general practice ${ }^{5}$ - where land tenure systems are predominantly private sector biased, including private ownership of subsurface mineral rights, unsevered from the entire land parcel - these exceptions are a marked minority view which evolving international practice on the question has not chosen to assimilate or replicate. In any event, the entire rationale behind the preferred legislative framework is predicated on the fact that the State, exclusively, owns its petroleum resources.

(2) Competent Authority - The PL should clearly identify a single government agency, or competent authority (CA), vested with the exclusive mandate to implement government policy in this area of petroleum development. The CA represents the State in negotiating and contracting with foreign investors and in regulating and administering, from both a policy and technical compliance viewpoint, the implementation of contracts once they have been signed. Ideally, the CA should be named in the PL, so that potential investors will know who will be their single point of contact with the government ${ }^{6}$. Preferably, it should be a ministry or other body having considerable sectoral expertise and experience. In most countries this role is played by the local equivalent of a Ministry of Energy or Petroleum. This

\footnotetext{
5. Notably the United States, excluding state lands, foderal lands, the continontal shelf under state jurisoliction and the outer continental shelf under foderal jurisdiction. In fact, desplte private land ownorehlp as a system, the Stato is by far the largest ouner of land in the U.S.A.

6. The concept popularly known in the Potroleum Industry as a "one-etop shop".
} 
body usually has responsibility for petroleum exploration, development and production.

Often, however, the state of petroleum development in a given host country will produce variants of this basic approach. This is particularly true at the extreme ends of the scale, where the host country is either a developed petroleum province or a neophyte to the sector. In the formier case, it is likely that the State has already created a national oil company (NOC), with varying degrees of experience and responsibilities. In addition, the State may also have vested the NOC with exclusive authority over the sector as the de facto $\mathrm{CA}$, allowing it to: allocate acreage by direct negotiation or tender, while, itself, retaining or competing for such acreage; contract on behalf of the State with the selected licensees or participate as State partner in joint ventures; and administer the petroleum contract and act as technical interface for the State with the licensec'. All of the above together is not recommended. Rather, a separate CA should hold the State's patrimony in its petroleum resources, conduct competitive bidding and/or direct negotiations and ultimately issue licenses to successful bidders. The CA should contract on behalf of the State, not the NOC. The NOC should not have authority both to allocate acreage to potential licensees and to

\footnotetext{
7. As was historically the cease, for eximple, in Indla, with ONeC; Romanla, with PETROM; and, most recenthy, Azorbeljan, with SOCAR. In cach case, Bank logal TA (ESMAP freo-etanding TA to the Ministry of Potroleum \& Natural Gas and ONGC) and project (Ln. No. 3723 RO; propoeod Enory Sactor TA Project, Azorbaljan) included or will include compononts to rectructure or rosilign the insthutional infiastructurs of the sector of the sector to move it away from such oxelushe authortly for the relevant NOC.
} 


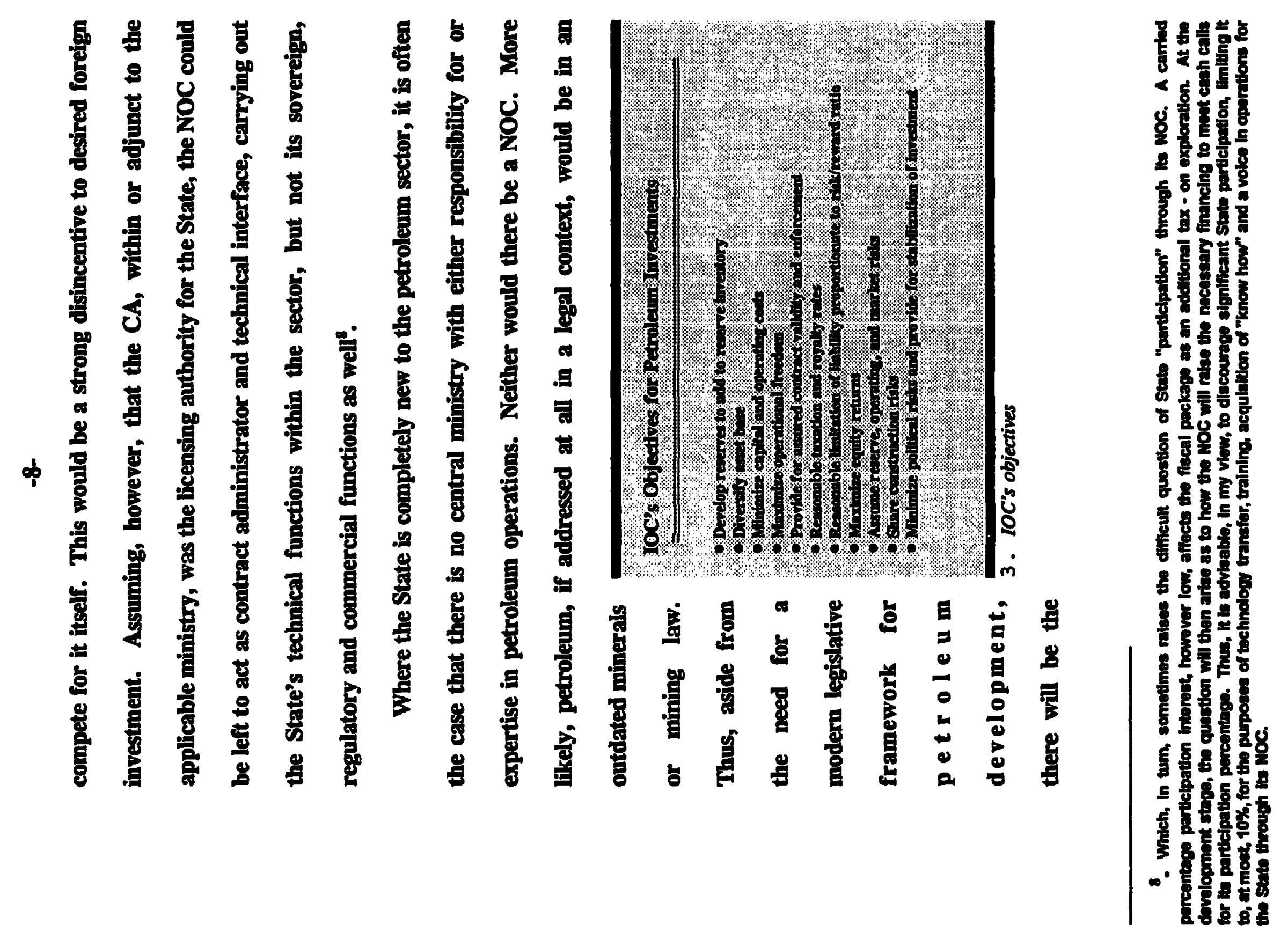


need to create a CA with adequate expertise and authority. This will require institutional strengthening and consensus. Rather than a competition between interested ministries - e.g. Geology; Environment; Commerce and Trade; Finance; etc. - it is often expedient in such case, as an interim solution, to constitute the CA as an inter-ministerial council or consultative group which has the full authority to license, contract and supervise petroleum operations'. Concurrently, expertise can be developed through experience, training and participation, ultimately leading to the creation of a true, separate $\mathbf{C A}$ with the requisite staff and mandate.

(3) Petroleum Operations - This essential provision has a twofold purpose. First, it is meant to ensure that petroleum operations are conducted only under a duly issued permit or license from the CA, in such form and on such terms as are prescribed in the PL, the Regs and, where applicable, a petroleum agreement (PA), the terms of which must be consistent with the enumerated requirements thereof in both the PL and the Regs. Second, it is intended to give the State the maximum possible flexibility as regards its means of conducting petroleum operations. This may be through a State authority, such as an NOC, a private entity, such as an incorporated joint venture, or in any other manner which it may deem appropriate - all within the bounds

\footnotetext{
9. As was proposed by ESMAP to Polkh authoritles under a PEPP conducted in parallal to Loan No. 3215 PL. The ad hoc "Inter-IInisterial Commission" would be comprised of representatives of the ministries of lndustry, Finance and Emironinental Protection, Natural Resources and Forestry, charged with full authority to consult, supervise and awerd petrolaum licenses.
} 
of established international norms and standards to attract foreign investment to a known and conducive setting in the sector.

(4) Petroleum Agreements - Under this provision of the PL, the concept and outline contents of a MC(s) is introduced. It authorizes the CA to have prepared and make available MCs to potential applicants as the State's starting point for the negotiation of an E\&P PA. In some PLs, a copy or copies of a MC(s) is appended to the law as an exhibit. This would enact the MC format as part of the PL. It is much better, however, not to follow this course. One must weigh the desirability of enacting a detailed, not easily changed or revised MC with the force of law against merely identifying its essential, minimum provisions in the PL - thus establishing their legal basis but leaving full details and negotiable points to the $M C$ as a flexible instrument, subsidiary in position to the PL. The latter course is recommended. The PL should be couched in terms of permissive, minimal contents of an MC - such as detailed in Section C. below - without legislating their provisions in detail. This is the "generic" aspect of such a PL, which provides only the legal underpinnings and thereby leaves the State maximum negotiating options.

Also to be covered in this section of the PL are the CA's primary roles in: negotiating and concluding PAs; directly or indirectly supervising petroleum operations under PAs; revoking or suspending PAs for cause, after due notice to the rightsholder and a reasonable period for it to effect cure; 
granting of non-exclusive prospecting permits for the purpose of obtaining information on hydrocarbon endowment; and, depending on how the PL is meant to interface with the State's mining law, if any, the granting of mining permits for areas already subject of petroleum operations, provided, however that the former does not interfere with the latter.

(5) Requlations - As earlier said, Regs should be subsidiary instruments to the PL and should not themselves be enacted as law. Rather, this section of the PL should expressly authorize the CA to make Regs from time-to-time, consistent with the policy and objectives of the PL. This gives the great advantage of flexibility to the regime, allowing for changes to be made quickly, in response to current developments, without the need for a protracted and often non-expert legislative process ${ }^{10}$. The safeguard, however, is that the Regs and any amendments thereto may never be inconsistent with the PL.

For greatest clarity, the PL should sring forward into its text for summary mention the general areas in which the CA may make Regs. These will be dealt with in greater detail in Section B., below. In addition, the PL should also give the CA broad authority to make any other Regs which it considers necessary to give effect to the provisions and policy objectives of the PL.

\footnotetext{
10. While this is the preforred, majority practice, a recent free-standing petroleum TA mission to Cyprus found that under its present PL, Regs are to be made by the Council of Ministers, acting as the CA. In addifion, the PL provides that such Reges will be onacted (or not opposed) by Cypriot parliament and, upon publication, become law. Thus the Regs and the PL together are law, rather than the desired, flexilble subsidiary Instruments under the latter.
} 
(6) Qualifications, Duties and Rights of Rightsholder or Contractor - First, it must be made clear in the PL that PAs shall only be concluded with applicants who have the requisite financial resources, technical competence and professional skills necessary to fulfill their obligations fully under such agreements. To this end the CA, as licensing authority, must have both the power and the duty to conduct "due diligence" inquiries on all applicants on such qualifications and to require of them satisfactory documentary evidence of same, as may be applicable. This due diligence by the CA also serves to avert the undesirable result of awarding a license or permit to a bidder which is not so fully qualified and which has bid primarily to acquire rights to prospective acreage for the purpose of assigning or promoting it on at a profit, without undertaking itself any significant work program.

The principal duties of a rightsholder under a PA should be enumerated in the PL and then amplified in greater detail in the PA itself. In the PL, the rightsholder's duties to be specifically mentioned, and replicated as terms in all PAs, include: reporting the discovery of any petroleum to the $\mathrm{CA}$; presenting the $\mathrm{CA}$ in timely fashion with a development plan for commercial petroleum discoveries and promptly taking all reasonable steps to develop and produce the discovery; conducting all petroleum operations in accordance with good international petroleum industry practice, including measures to promote conservation, safety and environmental protection; and indemnifying the CA against all claims made 
by third parties in respect of injury, damage or loss caused by or resulting from any operations carried out by the rightsholder or its subcontractors under a PA.

In return, the rightsholder under a PA should be accorded certain guaranteed rights in the PL, some of which are necessarily amplified in the PA itself. The fundamental right, however, is that the rightsholder be granted the exclusive right to carry out petroleum operations within the area covered by the PA, for the time period(s) specified therein, subject to the provisions of the PA. As a corollary to the principle that an investor need only negotiate and conclude its arrangement with a single governmental authority - the CA - the total arrangement between the parties should be included in the PA in contract form. Separate procedures involving further governmental discretion - such as the granting of a license or the conversion of a "prospecting or exploration license" into a "production license", as is prevalent in civil law-based PLs - are inadvisable, unless they are mere formalities, the validity of which is dependant on the PA ${ }^{\text {II }}$. Any feasibility studies, expert evaluations or requisite governmental approvals of a proposed arrangement should, thus, be obtained internally by the CA prior to signature of the PA.

\footnotetext{
11. The most recent example being the Bank's comments to this effect - which were duly accepted - to the draft Hydrocarbon Law of the Ropublic of the Congo. Enactment of such a sathefactory law is a condition of effectivenees to the Economic Recovery Credit, provided to the Congo in 1994 (Credit No. 2635 CG).
} 
Allowing for the prevalence of civil code systems in certain areas principally francophone Africa, the Middle East, Eastern Europe and the new Republics of the FSU - the question of the precise legal nature of the license or permit should be clarified in the PL. In this regard, there is a clear divergence of views between IOCs and host States. The former always wish to have the license characterized and treated as a contract and, consequently, to have the ability of the State to change the license's terms through subsequent legislation appropriately restrained. On the other hand, host States tend to treat the license as an administrative permit which will remain unchanged, except where made absolutely necessary by dictates of public purpose, and then, against the provision to the affected licensee of adequate and just compensation. This is especially true in civil code systems where the concept of the administrative contract is often applied to State licensing. To reconcile these divergent views, the PL should separately recognize the license as a permit and the PA as a contractual agreement, the terms and conditions of which are to be respected for its term, not to be changed without the concurrence of both parties ${ }^{12}$.

(7) Taxation of Profits - As earlier said, the tax/fiscal aspects of a complete petroleum E\&P legislative framework may either be detailed in the PL itself or separately set out in a companion PRC. The choice is often dictated by

\footnotetext{
12. Under the Potroleum Legislation Task for the Russlan Federation carried out under the Technical Cooperation Program, extensive discussions were hold with Rusalan ministorial and legislative countorparts resulting in the agread adoption of a contractul format for licenees to be granted under the Lleorising Statute implementing the provislons of the Undarground Rosources (Subsoil) Law.
} 
the depth and complexity with which the host State wishes to treat this topic. Normal practice, however, would be to establish the essential elements of the applicable regime in the PL in such a way that the potential investor may: easily gain a full understanding of the applicable tax regime; compute, without excessive uncertainty, the amount of taxes to be paid under such fiscal package; and consider such a fiscal package - taking into account the contractual arrangements - as reasonably competitive with other, similar worldwide investment opportunities.

As an overview, an appropriate petroleum taxation framework should, in the view of this writer, have the following broad objectives:

(a) reduce uncertainty on taxation to the maximum extent possible. The IOC should have a clear understanding of the taxation regime which is applicable to itself, its affiliates, personnel, sub-contractors and to its actual petroleum operations (imports, exports, turnover taxes, etc.);

(b) limit negotiations on tax issues, which should be ideally defined in laws and regulations, rather than under a PA (except for specific procedures and a number of negotiable issues);

(c) provide for a fair and equal tax regime, regardless of the nationality of the investor (domestic or foreign), without any significant discrimination; 
(d) avoid double taxation for foreign companies or IOCs by ensuring that profit tax paid to the host country will qualify for foreign tax credits under the tax laws of the country of origin of the investor while, nevertheless, assuring full resource rent capture by the host country ${ }^{13}$;

(e) provide for tax stability for a reasonable time period. In non-OECD countries investors are accustomed to benefiting from such stability, even though the host country has the sovereign right to amend tax legislation regularly;

(f) similarly, provide in PAs for reasonable "grandfathering" of tax regimes in existing PAs, unless otherwise mutually agreed; and

(g) design a tax regime that can readily be applied to any type of PA which may be entered into (production sharing contract [PSC], concession, joint ventures, etc.).

Whatever complexity and detail the host State ultimately chooses to include in its fiscal package for petroleum development, experience indicates that certain basic tax premises should be covered in the PL to establish the exact parameters or baselines of the operative fiscal regime excluding,

\footnotetext{
13. This is of particular relevance to $10 \mathrm{Cs}$ which pay taxes both to the host State and to their national State. US-based 10Cs are the prime example, while recent changes in UK tax laws have made this principle applicable to UK-based lOCs as wall. In such sltuation, the host Stato shouid set ths incone tax rate at loast as high as those generally applicable in the countries of nationality of nelevant OC Investors to be sure that the majority of the rent (tax) paid by the investor for the exploftation of the resource is captured by the host State.
} 
otherwise, all other generally applicable taxes and payments not so expressly named therein. This should include that:

(a) rightsholders under PAs will pay applicable taxes on profits (not revenues) from petroleum operations ${ }^{14}$. This may be either a specific petroleum profits tax (including additional profits tax [APT], as applicable) or the generally applicable profits tax rate;

(b) under a PA which is a PSC, the rightsholder may comply with its obligation in (a), above, by having its tax liability borne by the State partner on its behalf. This will be reflected in the production splits available to each party's;

(c) under a non-PSC PA, a royalty (ceiling and floor may be set in the PL) will be payable (as set from time-to-time by Regs, consistent with the PL, or as negotiated in the PA) ${ }^{16}$;

(d) other payments, such as annual rentals, contract administration fees, signature and/or production bonuses may also be payable (as may be negotiated in the PA), as well as any import and export taxes; and

\footnotetext{
14. In the now States of the FSU, this has been a prevalent problem from the outset, creating a significant dlaincenthe to desired foreign investment in the sector. Under various tasks of the Technical Cooperation Program and the ensuling petroloum londing program, considerable progress has boen made on this tax policy matiorin both Rusela and Kerakhatan.

15. The rightsholder's progressive production shares will be slgnificanthy lower, being nat of taxes to the hoet Stats. For the purposes of the foreign tax credit for US and UK-based rightsholders, it is equally important that production shares recehved on a "deemed tax-paid basis" include a transparent mechanism by which the applicable tax increment ls actanaly and demonstrably remitted to the host State's tax authorities.
}

16. Despite a minority "hy brid" practice to the contrany (0.9. as was initially propoasd in Loan No, 2152 24M), the majority practice is not to have a royalty payable in a PSC PA arrangement. 
(e) all other taxes and payments generally applicable to industrial undertakings and enterprises but which are not expressly made applicable to petroleum operations under the PL are excluded therefrom.

(8) Other Taxes, Duties and Exchange Controls - While import and export taxes and duties are, as said in (7), above, part of the overall fiscal package, practice is quite clear as to their relationship and applicability to petroleum operations. Uniformly, PLs and PAs specify that rightsholders, and those contractors and subcontractors working for them, are free to import and export supplies and equipment authorized under the PA for petroleum operations free of customs duties and taxes of any type. Expatriate employees of these parties receive the same treatment for their household goods and personal effects. To ensure that these exemptions do not become a mechanism for circumvention of the State's regular import controls, any item(s) so imported are made subject to the applicable duties and taxes if they are later sold within the host State for any purpose. Equally, these exemptions from taxes and duties do not automatically exempt the rightsholder from obtaining import and export licenses for the goods involved, if applicable. Such licenses permit the State both to consider the validity of the exemption on each item to which it applies and to enforce collections where a sale later occurs within its territory. 
As regards currency and exchange control matters, the PL must reflect the reality that to attract significant foreign investment into the sector, the host State should provide certain guarantees of convertability and remittability of funds to investors of risk-capital in petroleum operations. Free movement and exchange of funds is of particular importance in the international petroleum sector ${ }^{17}$. At the very least, IOCs are usually assured of the ability to convert and remit funds needed to meet current obligations and loan commitments. It is preferable, however, to ensure that such investors are able to convert their local currency profits from petroleum operations at non-diseriminatory rates of exchange and to remit them to shareholders without restriction. Admittedly, while this is not always easy for countries with balance of payments problems, it is quite necessary to foster development of the sector. Provided that the foreign enterprise conducting petroleum operations is in full compliance with its obligations under the PA, the PL should, thus, permit it to ${ }^{18}$ :

(a) bring such foreign currency into the host country that is needed for petroleum operations;

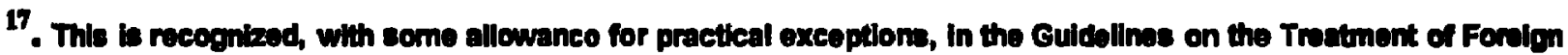

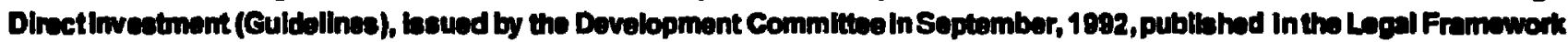
tor the Treatmont of Forelgn imvootmont, World Bank, 1982 and in 7 ICSID Rov.FIL 296 (1982). For a dotalied analyels of the Guldellnos, see Ibrahim F.I. Shihata, Legal Treatenent of Forelgn Investment: "The World Bank Guidelines" (1993).

18. While the above requirements are particularly tallored to the speclal needs of forelgn direct invectore in the potroloum eactor, they are conalatent wth the general provlalons of Article III, "Treatmont", Paragraphe 6.(1) and (2) of the Guldolines, relorred to gupere in foctnote 17.
} 
(b) obtain local currency for local purposes from authorized dealers at the most favorable legal rate of exchange at the time of conversion; use local currency available from affiliated companies; and borrow funds in local currency from host country banks, in accordance with the law;

(c) open interest-bearing bank accounts for foreign and local currency;

(d) pay foreign contractors, sub-contractors and expatriate employees outside the host country, provided it assures that these parties maintain enough foreign currency in the host country to pay taxes and living expenses;

(e) retain abroad all foreign currencies generated from sales outside the. host country; and

(f) export any foreign currency funds brought into the host counth. 'igr petroleum operations which prove to be surplus funds or which result from mandatory sales of petroleum to the State.

(9) Fiscal Stabilization - After a PA has been concluded, as an additional element of the total fiseal package, the investor should be secured where possible from the adverse economic effects of certain new statutes, regulations and laws. One way that this may be achieved in both the PL and PA is by using certain limited stabilization or renegotiation provisions. These provisions would mitigate the effects of any new enactments which either increase the burdens on rightsholders or reduce their original rights and economic benefits. As a 
further qualification, they would not apply to new laws imposing safety, conservation or environmental restraints, upon which the State must be free to act to protect the public interest. In such cases, newly enacted legislation will apply fully to the rightsholder, although this may be subject to a requirement in the PL for the CA, acting for the State, to negotiate in good faith amendments to the PA which would compensate the rightsholder for the resulting increased economic burden. ${ }^{19}$ Alternatively, the same result may be achieved without the use of express stabilization provisions. In host States where investment opportunities exist and the investment climate is perceived to be reasonably stable, the State's assurances that all contracts will be scrupulously honored - subject only to possible limited, non-discriminatory changes enacted for a public purpose and subject to just compensation for their effect - may well suffice.

(10) Environmental Protection and Safety - For far too long, international practice in the petroleum sector has lagged behind the pace of today's keen awareness worldwide of the need for diligent environmental protection and preservation. PLs often failed adequately to address the topic and there was no substantial backup position in comprehensive and modern laws on environmental protection and conservation in most host countries. Most frequently, the

\footnotetext{
19. The Presidential Decree No. 2285 (December 29, 1993) of the Russtan Federation entitiod "Questions of Production Sharing Agreements when Uaing the Subeoll" provides, in this regard, that "Tf during the perlod of operation of [a PA] norms are established by logislative acts of the Russtan Federetion which woreen the commerclal results of the actulty of the Investor within the framewrork of the [PA], changes shall be made therein which ensure to the investor the commerctal results which would have been recelved when applying the norms of leglalation that provalied at the moment of coneluding the [PA]".
} 
topic was left to a broad and bland obligation in both the PL and MC that rightsholder or Contractor was typically required to 'conduct all petroleum operations in a diligent, conscientious and workmanlike manner in accordance with... generally accepted standards of international petroleum industry designed to achieve efficient and safe exploration and production of petroleum...' Some such provisions went further, so as to require that all necessary measures also be taken for conservation, safety of life and property, crops, fishing and fisheries, navigation, protection of the environment, prevention of pollution and safety and health of persoinnel. While a reasonable beginning, this was all, still, iradequate.

Establisied practice today is to include a more comprehensive obligation for environmental protection and safety in the PL and then to detail more specific actions and requirements in both the Regs and the MC/PA. This will, almost without exception, include a requirement for an environmental assessment or impact study to be carried out prior to the commencement of petroleum operations ${ }^{20}$. There is, however, a possibility of thereby creating a significant short-term financial disincentive. Equally, in line with the premise that legislative regimes for petroleum development should be a self-contained, coherent legislative frameworks in and of

\footnotetext{
20. In this regard, the Bank, in fin: reing petroleum sector projects, now requires an environmental assessment and classlfication at or prior to apprabal $G$, the projoct. See the World Bank Operational Directive [OD] 4.01, Environmental Assessement, October 1991, and for specific application to petroleum projects, see the Emvironmental Assessment Sourcebook, Vol. 3, Guidelines for Environmental Assessment of Energy and Industry Projects, World Bank Environment Department, 1991.
} 
themselves, it is not recommended to make petroleum operations subject generally to any broad, comprehensive, non-Petroleum specific environmental protection law, if extant, except to the extent that the principles therefrom are applicable to specific sector practices.

(11) Miscellancous Provisions - To round-out a generic, enabling PL, the following topies should be covered briefly but succinctly:

(a) Definitions - every law of a technical nature should have a reasonably extensive "Definitions" section, all of which such definitions are then used consistently in the law, for both drafting convenience and accuracy of reference. Ideally, the Definition section should be at the beginning of the law, best to serve both purposes. In PLs in particular, accurate and precise definitions are a crucial element of both clarity and brevity;

(b) Natural Gas Development - particularly in host States which are known or expected to be gas-prone, it is advisable for the PL to provide for special incentives and priorities to encourage the development of natural gas (also a defined term) ${ }^{21}$. Historically and for too long, natural gas was treated as the "poor relative" of crude oil. Only relatively recently has its real potential been realized as an abundant, worldwide environmentally clean and economically efficient fuel. Recognizing, however, that while natstral gas may be found and

\footnotetext{
21. Thls was done for gas-prone Bangladesh in the PL and MC prepared under a Bank-Financed PEPP (Credit No. 1402 BP).
} 
produced in the same way as crude oil, it thereafter differs considerably from the latter in physical properties, characteristics and, most importantly, in its development, transportation and the limited geographic radius from its source of its economic uses. It is not, then, "another form of crude oil", to be treated as such, mutatis mutandi. Rather, enlightened modern PLs have specially-tailored gas development and commercialization provisions to encourage positive action on gas discoveries. These include, inter alia, provisions to: appraise for the State (even if the rightsholder does not wish itself to attempt commercial development); allow the rightsholder a longer development or retention period to conduct a market feasibility study; and optionally to develop jointly with the State in a negotiated joint venture. In summary, practice today dictates that a PL being drafted for a known or likely gas-prone host country should include special gas development provisions such as those mentioned;

(c) Unitization - when rightsholders on adjacent blocks know, prove or have reason to believe that they each have discovered petroleum from a common structure which extends across the boundary line of their respective blocks, the State has a paramount right to ensure that in the interests of economy, efficiency and conservation of the resource, the common deposit is developed as a single unit, on a non-competitive basis by the interested rightsholders. This is the procedure called 
"unitization". Unitization prevents wasteful competitive drilling by rightsholders to the prejudice of the State's interests as the resource owner. Common practice is to include a provision in the PL giving the $\mathrm{CA}$ the right to order the affected rightsholders to develop such an area jointly, or under a joint operating or unit plan, approved by the CA;

(d) Access to Land for Petroleum Operations - remembering that legislative frameworks for petroleum E\&P development should, to the greatest extent possible, be self-contained and coherent, issues of land use for petroleum operations should be both specifically addressed in the PL and harmonized therein with any broader-based land law in force. In particular, the PL should guarantee the rightsholder necessary access both to public and private lands for the purposes of carrying out procedures necessary and incident to its petroleum nperations. The conditions of such qualified rights of entry and use should be spelled-out in Regs made by the CA, which should include a provision for payment of fees to the State as consideration and compensation to landowners and occupiers whose rights have been disturbed. Presumably, the State will already have the power temporarily to appropriate or burden private lands for public policy purposes - such as for petroleum development - against the payment of adequate compensation under the broader land law. If not, such 
should be specifically provided in the PL for the purpose of facilitating petroleum operations ${ }^{2}$;

(e) International Arbitration - certain disputes between parties to a PA a foreign IOC and the CA - which cannot be settled by other means should be made referable under the PL, at the request of either party, to settlement by international arbitration under the rules and auspices of one of the recognized international arbitral fora. Not all disputes should be made subject to such international arbitration, however. Those to be arbitrated should be limited strictly to controversies involving the interpretation, validity, execution or termination of a PA. Assurances that such disputes will be decided by a knowledgeable and impartial decision-maker is of particular importance in the international petroleum sector. Controversies involving laws or regulations not directly related to the $\mathrm{PL}$, however, remain within the jurisdiction of the courts of the host country. Recognized and suitable international arbitral fora include: ICSID, a Bank affiliate; the Stockholm or London Courts of Arbitration; the court of arbitration of the International Chamber of Commerce in Paris; and the arbitration centers of the Afro-Asian Legal Consultative Committee in Cairo and Kuala Lumpur, as major examples. It would be necessary

\footnotetext{
22. While these concepts of "compulsory taking" or "eminent domain" were already known, their procedures were not clearto several of the FSU Republics. This engandered considerable discussion and explanation, for example, with Russian counterparts under the Petroleum Legislation Task of the Technical Cooperation Program.
} 
for both the host State and the State of the IOC's nationality to be a party to those fora established by international conventions, such as ICSID; and

(f) Affected Leqislation/Relationship to Other Laws - the PL must clearly state its relationship to other relevant legislation. Practice is that all matters concerning petroleum should, to the extent possible, be covered by the PL. If this is not possible, the PL should, at the time of its promulgation, be made specifically to prevail over any conflicting requirements of other existing laws or regulations. Such conflicting laws and/or regulations should subsequently be amended to remove such conflicts, but the principle of precedence of the PL should be clearly enunciated therein. As an intermediary step, however, the PL may specify certain transitory periods or delays to its full force and precedence, pending other necessary legislative action or the making of amendments to conflicting provisions of other laws.

\section{Regulations to a Petroleum Law}

It is my view that the second essential component of successful petroleum legislative frameworks for E\&P development are the Regs to the PL. As discussed in paragraph (5) of Section A., above, the PL should authorize the CA expressly to make Regs, from timeto-time, providing the detail and procedures by which to implement the policy and objectives of the PL, by reference to specific, enabling provisions thereof. As also earlier explained, the Regs are subsidiary instruments to the PL, not intended for legislative 
consideration or enactment. The benefit in this practice is that maximum flexibility is maintained, allowing for timely response to any current developments which would require changes in the Regs. The safeguard, always, is that the Regs, and any such changes thereto, may never be inconsistent with the policy, objectives or letter of the PL.

Consistent with the types of legislative formats discussed here, the Regs to the type of PL detailed in Section A., above, will follow the PL's format, adding the detail necessary to effectuate the intent of its enabling provisions. This may be quite extensive or not, depending on many variable factors. Regardless of length or brevity, however, particular attention and elaboration in the Regs should always be given to the following core items:

(1) Competent Authority - In the event that the PL does not itself identify the single government entity or agency that will act as the CA, such entity or agency should be identified in the Regs. The policy advantage of such an approach is flexibility. The concept of the CA must be established by law, but its identity may be more readily changed by Regulation in response to evolving circumstances and growing or shifting expertise within government. The caveat, however, from experience, is that frequent changes in the identity of the CA will prove a disincentive to foreign investment, due to perceived instability and lack of continuity of the entity.

To the extent that the exclusive mandate in the PL for the CA to implement State policy in the petroleum sector does not fully enumerate all of the CA's specific powers and duties attendant thereto, the practice is to set them out in detail in the Regs. It is also possible to address in the Regs the 
structure and composition of the $\mathrm{CA}$, but it would be better to do so in a separate constitutive document or decree, as this is more an administrative matter than one of sectoral substance.

(2) Petroleum Licensing - As the PL establishes both that the State exclusively owns all petroleum within its territories and that it may conduct operations through any entity or in any manner to develop such petroleum, including the licensing of its exclusive right to qualified applicants under a PA, the Regs must detail the methods by which such licensing may be accomplished.

Established practice is first to delimit prospective petroleum acreage and then to offer it for licensing by officially and publically advertised bid tenders. However, where acreage is not included or planned to be included in such a bid tender, the CA should also be permitted in the Regs to enter into direct negotiations for the licensing of same by an interested party, upon its valid application. In order to receive the most competitive offers, however, bid tender is preferred where petroleum industry interest is either anticipated or preliminarily evident ${ }^{23}$.

(a) Contract Area - Before licensing procedures can commence, the $\mathbf{C A}$ must first accurately identify the areas to be offered. Normal practice is to provide for the principle of "graticulation" (geographic demarcation) in the PL and then to deal more specifically with it in

\footnotetext{
23. The tranaparency and broader spectrum of competition are the strengths of the bid tender process. The often sated fear of direct negotiations stems from the possibility of both corruption and sharp practice by elther the State or applleant partios.
} 
the Regs. In this regard, the Regs should specify a uniform shape for areas to be offered (Contract Area). This is generally that Contract Areas should be geometrically regular in shape - normally a 3:1 rectangle - oriented north/south or east/west. As to sizing of Contract Areas, the usual practice is to specify in the PL both minimum and maximum areas to be allowed (in square kilometers), leaving it for the CA to determine individual Contract Areas within these permitted limits.

(b) Bid Tenders - The Regs should outline in detail the procedures by which bid tenders will be conducted. This is subject to numerous variations, but should always cover, inter alia:

(i) issuance of a bid package by the CA which includes - an accurate map of the area(s) open for bid; a brief description of the geology and topography of the offered area(s); a bid sheet listing the criteria for bid evaluation and providing a format for bidders to submit their proposals; a MC(s), to which bidders must identify any exceptions; the procedure for submittal and evaluation of bids and the subsequent negotiating process; and the amount of any bid guarantee to be submitted, 
set in an amount both to encourage the widest competition and to discourage less than serious bids ${ }^{24}$;

(ii) the requirement that the $\mathrm{CA}$ shall publish in the ofricial government journal or newspaper a brief description of the areas to be subject to the bid tender, the proposed petroleum operations to be conducted (e.g. new exploration; development; enhanced recovery; workover) and instructions for obtaining bid packages. The CA should also be given discretion both to publish similar such notices in domestic and foreign business and trade publications and to send them directly to bidders whom the CA believes may be interested ${ }^{25}$;

(iii) discretion to the CA to require prospective bidders to purchase geological and geophysical data, well logs or other proprietary information owned by the State concerning the area(s) subject to the bid tender. In such case, the Regs should require that the description and price of such bid package shall be included in the notice to prospective bidders, discussed in (b), above.

\footnotetext{
24. The evil to be prevented here is "promotion" by an applicant which doesn't have elthar the financlal or technical capabilities to fulfill the pioposed MWO. Too often, States now to the sector will award licenses to such companies, under questlonable circumstances, which such companies will, in turn, seek to sell, assign or "farm-ou" afl or most of thair rights to an IOC at a significant profit, having made no real monetary or work expenditures. While the Bank will not comment directly to a host State on the merits of any such license or PA awarded, it will seek, if requosted, to domonstrate to the host State best practice in the sector, as a comparison or benchmark.

25. Under Bank-financed PEPPs, in addition to broad, Intemational trade publication of intendad licensing rounds by host States, such projects include a component for one or several promotion seminars for intenestod Industry companies in the host State's capital clty, as woll as in international oil centers such as London, Houston, Singapore, ofic.
} 
Concerning the price to be charged for bid packages, the preferred practice is to limit it to an amount adequate to cover the cost of its production and/or the administrative costs of the bid tender ${ }^{26}$; and

(iv) as regards the processes and procedures of bid submission, evaluation, award and negotiation of a PA, the Regs should specify them in detail in clear, transparent fashion. In particular, provision should be made for: (i) the submission of sealed bids; (ii) their public opening; and (iii) procedures for their evaluation and a maximum time limit for the $\mathrm{CA}$ to conclude same and to negotiate a PA. The procedure is to rank in order of their merit all responsive and competitive bids - factoring in as well an evaluation of the bidder's technical and financial competencies - and to notify the first several (e.g.- three) ranked applicants. Thereafter, the CA will begin negotiations, based on the MC, with the highest ranked bidder, mandated to conclude a PA therewith within a maximum time limit (e.g. 60 days), or to commence fresh negotiations with the next ranked bidder(s). Alternatively, the CA may reject all

\footnotetext{
26. The preferred practice is for the host state not to seek to make a signifleant profit on the sab of bid data packages. This can bo a real disincentlve to attracting Industry Interest. The more difficult ease be where a State contracts with a private geophysical company to acquire and prepare a data package for cale at cost plua a profit-margin to the independent contractor.
} 
bids and either re-bid the area(s) or withdraw all or part of it from the bid tender.

(c) Direct Nerotiations - As earlicr said, acreage which is not included or planned to be included in a bld tender should be permitted in the Regs to be licensed by the CA through direct negotiations. A party interested in entering into direct negotiations with the $\mathrm{CA}$ should be required to provide to the CA sufficient information fully to identify: itself, as a corporate or other entity; its arca of interest, defined by geological coordinates; its technical competence and financial resources, fully described and documented; and complete terms and conditions it proposes for a PA. Thereafter, at the CA's discretion, it may enter into such direct negotiations with the applicant on such terms as it may deem appropriate, provided that they are consistent with both the PL and the Regs.

(3) Petroleum Operations - Under this heading, the Regs should address specific requirements to be met in the carrying out of petroleum operations under a PA. The most important of these normally include:

(a) submission to the CA of the rightsholder's annual work program; timing and procedures for its approval;

(b) prompt supply to the CA of quality copies of all gfilogical, geophysical, well and other technical data developed for a contract area, subject of a PA, by the rightsholder; 
(c) rightsholder's obligation to use only the best available machinery, equipment and supplies in petroleum operations, in accordance with international best practice;

(d) rightsholder's guarantee of reasonable and timely access for CA personnel to all areas upon which petroleum operations are conducted under a PA;

(e) rightsholder's obligations with regard both to advance notification to the CA of the drilling of any proposed well and the former's duty to plug and abandon unsuccessful wells in an environmentally and safetyconscious manner; and

(f) the requirement and procedures by which the rightsholder under a PA must meter and measure petroleum produced and transported from a Contract Area for the purpose of accounting for it to the CA.

(4) Petroleum Agreements - Some PLs have attempted to legislate the entire content, in detail, of what must be included in a $\mathbf{P A}^{27}$. Alternatively, some Regs go into such extensive detail, in lieu of legislating it in the PL. The former option is definitely not recommended; the latter, while less disfavored, is normally counterproductive. As earlier noted, it is better to have the PL enact the core concepts of the legislative, contractual and fiscal regime - in broad outline but not in specific detail - and for the Regs to elaborate such

\footnotetext{
27. As was the case with the origlnal draft PL, prepared by non-Bank-financed legal consultents, for Azerbaljan. Under the proposed Energy Sector Technical Asshatance Project for this member, such an approach will be abandoned and a PL, of the type discusesed in this paper will be prepared.
} 
core concepts, as necessary. The actual contents of the proposed PA consistent with the escential requirements set out in both the PL and Regs would, ideally, be contained in an MC(s), which, as a subsidiary, non-enacted instrument(s), would be the starting point for the State's negotiations of PAs. Consistent with this legislative scheme, the Regs, amplifying the enabling provisions of the PL, should address the following essential PA points:

(a) Contract

phases:

Finst PHASE, 3 YEMRS

terms - it

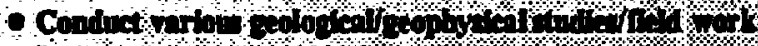

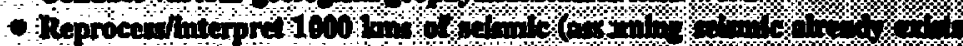
whith the sire).

should be

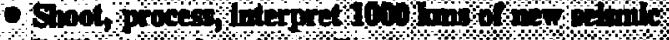

O Dell onderplorition well

established

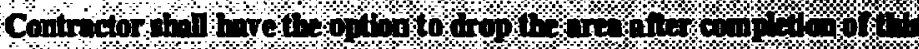

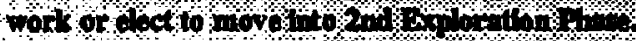

clearly in

SICOND PHASE, 2 WLIS

the Regs

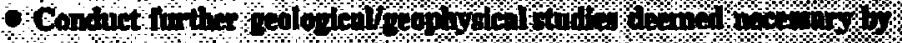

Contrinetor

that E\&P

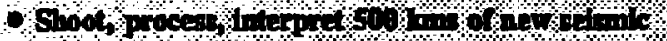

- Dritlone enploretito r il

PAs should

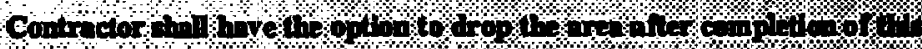

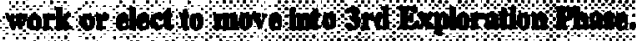

h $\mathbf{a} \quad \mathbf{v} \mathbf{e}$

\section{THIIRD PAASE, 2 YTE. ins}

separate

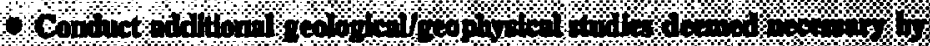
Coulis ctor

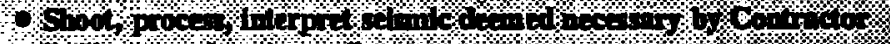

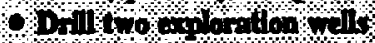

and distinct

phases,

being the

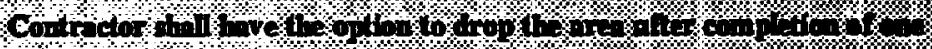

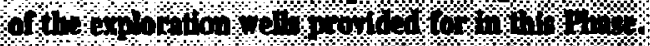

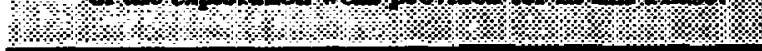

4. Exploration Period

exploration, appraisal and exploitation or development periods. The 
Regs should not specify mandatory terms for each such phase but, rather, set maximums periods for each of them, with provision for the possibility of a defined number of extensions of a maximum term each2. The actual phase terms to be agreed with each rightsholder should then be negotiated, within the specified maximums, and set out in the appropriate clause of the PA.

(b) Minimum work oblipations (MWO) - the Regs should mandate that PAs will provide for defined, minimum petroleum operations to be performed by the rightsholder during each phase of the contract, or other periods of time within such phases. These MWOs must be expressed in quantitative terms (e.g. number of wells and/or meters to be drilled; kilometers of seismic lines to be acquired) or in monetary terms (monetary value of each MWO committed). Preferred practice, however, is that the MWO be expressed in quantitative work obligations with line-item monetary values assigned to each such obligation, payable as a senalty in the event of their nonfulfillment.

In addition, the Regs should establish the principles that while the rightsholder may credit work undertaken in excess of the MWO for a given term to an ensuing term, its failure to perform the MWO for any given term will give rise to penalties, including payment to the CA of the value of the MWO not completed, termination of the PA, or

\footnotetext{
28. Thls might be, for example, a maximum of five (6) years for explorntion, with up to three (3) extendons of ons (1) year each; a maximum of twonty fwe (25) years for dovolopmont, with up to two (2) extorisions of tive (5) years each.
} 
both. To ensure that the CA will receive payment for the value of MWO items not completed, the Regs should specify that the rightsholder must secure either a bank guarantee or an irrevocable standby letter of credit in favor of the $\mathrm{CA}$, on a line-item basis, against the total value of the applicable MWO, which such facility may be drawn down on demand by the CA in cases of non-performance or default.

(c) Relinquishments - consistent with international practice, the Regs should require that PAs provide for periodic relinquishments of contracted acreage during the course of the exploration phase and any extensions thereto. This will be done within both the times and the percentages set forth as guidelines in the Regs and then negotiated as firm commitments, consistent with the Regs, in the $\mathbf{P A}^{20}$. The objectives of such periodic relinquishments are to ensure that by the end of the exploration phase of a PA, all acreage contracted but not to be commercially developed (the latter may be retained) is returned by the rightsholder to the $\mathrm{CA}$ in an orderly, geometric pattern, which is suitable for re-offering under a subsequent PA.

(5) Fiscal and Financial Regime - As earlier indicated, regardless of the complexity of the final fiscal regime chosen, its essential elements should be set out generically in the PL and then treated with more specific detail in the Regs. The advantage, as mentioned, of such an approach is the flexibility of

\footnotetext{
29. A typical mandatory rellnqulshment pattern for a seven (7) year maximum exploration phase might be: twonty five percent (25\%) of the original Contact Area two (2) yeare; fitty percent $(50 \%)$ of same after four (4 years; and all portions of the Contract Area at the end of the initial exploration phase, other than those areas retained for commorcial dovelopment or under an extension to the intital torm.
} 
being able easily to change particular rates and percentages in response to evolving circumstances, consistent always, however, with the principles and guidelines established for same in the PL and individually agreed in PAs. Thus, this section of the Regs may, from time-to-time:

(a) set the flat rate or range of a sliding-scale, negotiable royalty, if one is to be payable under a non-PSC regime;

(b) similarly, set the rates or ranges for land rental and/or contract administration fees, payable annually to the CA;

(c) establish the points during petroleum operations when bonuses may be payable (e.g. signature; commercial discovery; production levels), normally as quantitatively agreed in a PA;

(d) under a PSC regime, indicate both the acceptable ranges of production splits for profit oil, as between the State and the rightsholder (the latter on an income tax deemed-paid basis) at indicative levels of production, as well as the acceptable ranges or levels of cost recovery allowable to a rightsholder out of cost oil, all as may finally be negotiated in a PA ${ }^{30}$; and

(e) in a tax and royalty regime (i.e.-non-PSC), confirm the application or limitation of the generally applicable profits tax to rightsholders' petroleum operations profits and/or provide the rate of any petroleum

\footnotetext{
30. The indicative levels of production will normally be at eteps from 25,000 to 50,000 to 100,000 to 150,000 to In exease of 200,000 BOPD for nomel commorclal fields. A 30\% to 50\% range of cost recovery is quite nomal. Above $70 \%$ would be oenorous, but a definite incentlve to investmont where pros pects may be thought to be marginal.
} 
revenue tax (PRT) in lieu, as well as set rate ranges for any APT, leaving its applicable thresholds to be negotiated in a PA. ${ }^{31}$

The practice here is to specify in the Regs that, with regard to accounting for revenues and profits from petroleum operations, rightsholder will maintain clear and accurate records, in an agreed unit or currency of account, consistent with international petroleum industry standard accounting practice, and provide periodic (e.g.- monthly; quarterly) reports thereon to the CA, pursuant to the requirements and formats contained in an Accounting Procedure mandatorily A simplinied example of the royalty and tax mettiodology appended to the PA.

Lastly, this section of the Regs should set forth internationallyrecognized method(s) to value calculation for a Heche or Concession might be as follows: - 0 -000000000000000000000000000

1. Gross Dally Preduction

2. Royalty Rayobleto the Stinte $15 \%$

Gross Production Ieso Royalis

3. Contrictors Opernthys Bxpenses,

Other Tax Dedictlons Net Taxomble Incouit

4 PRT - $40 \%$ of Taxoble Incouse Contractors share of Protuction state's ile moton
100,000 rooro

150000000

85,000 10PD

10000QPPD

\%, 000 BOPD

3onoloop

45,000 NOFO

\$5,000 15010

crude oil and natural gas produced from a Contract Area, ultimately to be agreed and confirmed in a PA.

31. The purpose of APT b to catch true "windiall profits" on very large olfifelds. Not to discourege development of normal or marginal olfirelds, however, the thresholda of cumulative or gross production at which APT attaches should be set quilte high. 
(6) Assignment of Rights - As it may often be the case that a rightsholder under a PA may subsequently wish to transfer or assign all or a portion of its rights thereunder, either to its own affliate; another member of its consortium (if applicable); or to a third party, the Regs must address such a process expressly. In this regard, the practice is to allow such assignments, as follows:

(a) to an affiliate ${ }^{32}$, on prior notice to the $\mathbf{C A}$, but without the necessity of its prior consent, provided, however, that the assignor remains liable for the performance of the agreed MWO;

(b) to other consortium members, on a minimum of $\mathbf{3 0}$ days prior notice to the CA, with consent therefrom, such consent not to be unreasonably withheld; and

(c) to a third party, on a minimum of 60 days prior notice to the $\mathrm{CA}$, only with consent therefrom. Such notice must include all information concerning the proposed transferee which is required of an applicant for a license or permit, $\underline{a b}$ initio. The notice must also include an unconditional undertaking by the proposed transferee to be bound by all of the transferor's obligations under the $\mathbf{P A}^{33}$.

\footnotetext{
32. An "affillate" will be a dofinad term in the MC or PA. The operattve part of the definition will be that the Contractor owns, directly or indirectly, a majority of both the equily and voting control of the affillate. While best practice is to allow an assignment to an affiliate on notice to the CA but without the need for tis prior consent, this will always be coupled with Contractorlassignor's ongoing liability under the PA on a joint and several basis with tis affillate.

33. Where assignment is to be to a third party, Contractorlaselgnor must abo first show that it is olther current on

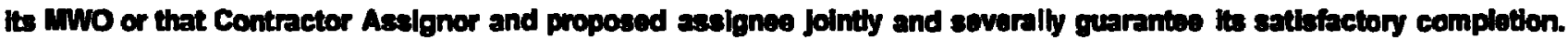
In this regard, it must be clearty demonatrated to the CA in the asalgnument appilcation that the proposed assignee has the requisite financial and tochnical resources to carny out the potroloum oporations.
} 
Thus, any such transfer or attempted transfer or assignment, other than (a), above, without the express approval of the $\mathrm{CA}$ would be both null and void and would constitute valid grounds for termination of the PA.

(7) Land Use - As previously noted, the PL must guarantee the rightsholder necessary access both to public and private lands for the carrying out of petroleum operations. In this regard, the practice is for the Regs to require the CA to deliver to the rightsholder, at the time of its signing the PA, all licenses and permits of every nature required under existing legislation for the conduct of petroleum operations, including those which allow rightsholder reasonably to use public and private lands, roads, means of communication, water and minerals for such purpose. Where privately-owned land is to be so encumbered, the practice is for the Regs to require good faith negotiations by the rightsholder with the owner(s) thereof and payment of just compensation thereto if voluntary agreement is reached. Failing voluntary agreement, the Regs should empower the CA to institute proceedings under the applicable Land Law for the State-taking of such lands - either temporarily or permanently - on behalf of the rightsholder, subject to the rightsholder paying both the adjudicated just compensation to the landowner and the administrative costs to the $\mathbf{C A}$ which it incurred by having undertaken and conducted such proceedings.

(8) Environmental Protection - As noted in paragraph (10) of Part A., above, evolving practice today on this topic is to amplify the obligation for 
environmental protection in the PL with specific details and required actions in both the Regs and the MC. The Regs may be as detailed as may be deemed necessary, but in the process of establishing norms of conduct, they should focus on the broad principles of:

(a) minimizing ecological damage;

(b) avoidance of waste to petroleum and its production environment;

(c) prevention of pollution and waste to land and structures, fresh water resources, crops, marine and animal life;

(d) emergency clean-up obligations and procedures; and

(e) restoration of the environment at the conclusion of petroleum operations.

(9) Miscellaneous Provisions - As first said, Regs to a PL may be either quite extensive, or not, depending on many variable factors. The guiding factor always, however, is not their length or brevity but, rather, that they provide the necessary detail and procedures needed for the full implementation of the policy and objectives of a generic-type PL. Within this overriding parameter, some items may be deemed more important than others for detailed treatment in the Regs. As this will vary considerably from State-to-State, depending on its legal system and sectoral or national priorities, this section concludes by briefly enumerating other important items which may require special consideration and elaboration in Regs to a PL, as follows: 
(a) Definitions - established practice is to incorporate by reference all definitions from the PL into the Regs and then to add, as necessary, any additional ones which may be required;

(b) Records and Reports - the rightsholder is always required under the Regs and in its PA both to keep full and accurate technical, geological and geophysical records of all petroleum operations conducted for review by the CA, on demand, and to report regularly and periodically to the CA on such operations at the intervals and in the format(s) required by the Regs;

(c) Accounts - the rightsholder is also required under the Regs to maintain and to submit periodically to the CA, pursuant to the agreed schedule in the PA, full and accurate accounts of all quantities and qualities of petroleum produced from the Contract Area and the ultimate disposition of same $\mathrm{e}^{34}$;

(d) Production Rates - it is generally discouraged for the CA to set or mandate production rates for reservoirs and Contract Areas. Rather, the international standard which the Regs should recognize instead is maximum efficient rate (MER), which is the rate of production from a reservoir which achieves the maximum, ultimate economic recovery of petroleum;

\footnotetext{
34. That $b$, elther sold or refined, in the case of crude oil; or, in the case of natural gas, reinjoctod, treatod (0.9.

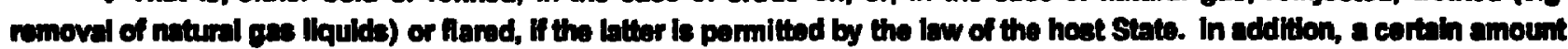
of production may be validly consumed by Contraetor in conducting petroloum operations.
} 
(e) Measurement of Petroleum - the Regs should require the rightsholder to measure, meter and weigh all petroleum produced by methods customarily used in good oilfield practice, as approved by the $\mathrm{CA}$, and periodically to test and recalibrate, as necessary, all such equipment used in the processes;

(f) Confidentiality - the Regs will mandate, and the PA will amplify, the obligations of both the rightsholder and the State mutually to maintain confidentiality, for defined periods, over information, documents, data and materials related to a Contract Area and acquired or exchanged between them in the course of petroleum operations;

(g) Indemnity - the Regs should require the rightsholder under a PA both to indemnify the State or the CA and to hold it harmless from all loss or damage to third parties or property caused by or occurring in the course of the conduct of petroleum operations; and

(h) Penalties - the Regs will set out offenses in contravention of the PL and the Regs, along with a schedule of penalties for individuals or corporate entities found guilty of any such offenses.

(10) Model Forms - To facilitate application for a license or permit to conduct petroleum operations under a PA, it is useful to append to the Regs as

\footnotetext{
35. Typleally, the CA may disclose data obtained from the Contractor's conduct of petroleum operations to prospective new applieants for portione of the Contract area already relinquished by the Contractor. Otherwise, both the Ca and the Confuctor are bound to compiate confidentialihy during the term of the PA (absent mutual consent otherwise), and the Contuctor for anymore from three (3) to eight (8) years after the termination of the PA, unless the data in question eariler becomes part of the public domain.
} 
annexes model forms to be used by the applicant or prospective rightsholder in making such application either under a bid tender or for direct negotiations. These model forms will be keyed to specific requirements in the PL and Regs, covering such basic requirements/information as:

(i) Basic Information on Applicant;

(ii) Contract Area Application/Bid;

(iii) Proposed Schedule of Bonuses; and

(iv) Land Rentals and Administrative Service Fees.

\section{Model Contract(s)}

This author believes that the final essential component of successful petroleum legislative frameworks is one or several variants of a MC. Some may not consider this element quite as essential, but to repeat, in my experience, a State is best served by having its own, purpose-crafted contractual format from which to commence negotiation of PAs. The MC(s) should be included in the bid tender package, requiring applicants to identify any exceptions thereto as part of their bid.

As earlier observed, the contents of a MC will flow from the permissive, generic requirements of the PL, as elaborated more fully in the Regs. In this regard, this paper will focus on both the essential provisions of an MC and those which are also negotiable.

(1) Scope, Duration, and Grant of Rights - After a brief Preamble identifying parties (State or CA and rightsholder, hereinafter called the "Contractor"); reaffirming the State's exclusive ownership of all Petroleum in its territory; and expressing the State's satisfaction that the prospective Contractor has the 


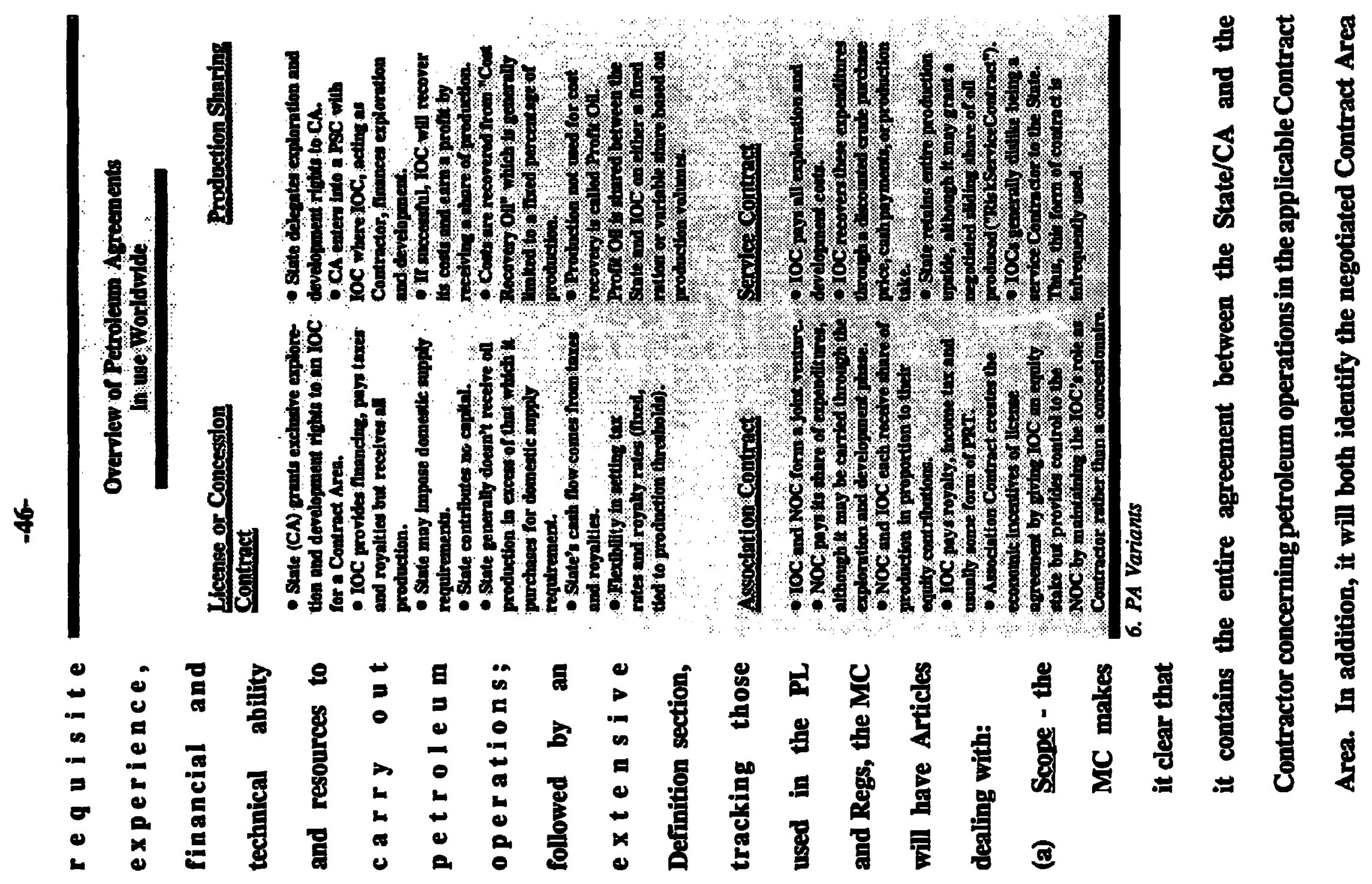


in square kilometers and by geographical coordinates - as described in a map to be annexed - and define the scope of the agreement between the parties, with the rights and obligations of each which flow therefrom;

(b) Periods, Phases and Terms - the former being exploration, appraisal and production. The terms for such periods are negotiable, within the maximums, for each set in the Regs, with any permissible extensions thereto. It will also be established here that the Contractor may relinquish and terminate at the end of the exploration or appraisal stage, provided it has satisfied the MWO for each; and

(c) Grant of Rights - herein the CA, for the State, will grant the Contractor its rights over the entire agreed Contract Area for the duration of a PA. It will make such grant effective upon execution of a PA by both parties.

(2) MWO. Work Program and Guarantees - which are essential, core provisions. The proposed MWO will have been submitted in the bid and subsequently will be negotiated. The MC will provide a format to insert the MWO agreed for the exploration period, and any extensions thereto, by contract year. This will be defined obligations to carry out additional, agreed geological and geophysical work and to drill a minimum specified number of exploratory wells. The MWO will be carried out through an annual work program and 
budget which will require approval by the JM[A]C, discussed in section 5., below.

To support the MWO and the annual work program, the MC should require the Contractor to provide an unconditional bank guarantee or standby letter of credit in favor of the CA, setting out the negotiated US dollar or other hard currency amount of such guarantee for each phase of the exploration period, by line item ${ }^{36}$. Provision is then made for the scheduled reduction of the guarantee on certification by the $\mathrm{CA}$ to the issuing bank that the work in question has been completed. In addition, it is desirable to have a guarantee from the ultimate parent company of the Contractor that it will provide all technical and financial resources as are required by its subsidiary to conduct petroleum operations ${ }^{37}$. The approved form of guarantees will be appended to the MC as an annex.

(3) Relinquishments - covers mandatory relinquishments by the Contractor during the course of the exploration period. These will be negotiated and inserted as progressive percentages of the original total Contract Area. At the end of the exploration perind, the Contractor will have either relinquished the entire Contract Area - having fulfilled its MWO - or all but

\footnotetext{
36. For example, Contractor's MWO may require the drilling of at loast two (2) exploration wells during the initial exploration term. If the Contract Area were to be ofishore, in moderate water depth, such wolls might average five milition equivalont US dollars $(\$ 5,000,000)$ each. The guarantes or standby letter of credit would, thus, earry each such committment well and th valua as a flne ltem, to be alther reducod accordingly when completed, or drawn down, in case of dafault on auch them by Contractor.

37. While such a guerantes is desirable and often obtalnable, parent companies will ranely go as far as providing a full, unconditional financlal guarantee of the Contractor undar a PA. In preference, they will offer a comfort lettor, afiiliete guarantiee or bank guarantee Instead. Property dram, the latter two could provide adoquate assurances to the host State.
} 
those portions in which it has made a commercial discovery of petroleum, which will then go on to development.

(4) Declaration of Commercial Discovery - elaborates the process by which a discovery of petroleum may be deemed sufficient for commercial development. The key principle here, no matter how expressed in an MC, is that only the Contractor may decide if a discovery is commercial for the purposes of its subsequent development by the Contractor. After promptly reporting a discovery to the $\mathbf{C A}$, the Contractor must first elect whether or not to appraise it. If it chooses not to do so, it must immediately relinquish the discovery area. If it does elect to appraise, it must do so within a specified time period, under a separate appraisal program, and then submit an evaluation of the appraised discovery to the CA. At such point, the Contractor alone decides whether or not the discovery is commercial, warranting its development by it. The firm principle is that the State or CA may not impose greater obligations on the Contractor than it agreed to under its PA - i.e. to compel it to develop by deciding on commerciality, against the Contractor's own judgment. The safeguard for the State is that if the Contractor decides that the appraised discovery is non-commercial, it must relinquish it fully and finally to the $\mathbf{C A}$.

(5) Joint Management [Advisoryl Committee - The JM[A]C is the consultative forum and supervisory body for petroleum operations under PSCs or association contracts. It will be composed of equal number of representatives 
of the State and the Contractor, with its chairman typically being appointed by the Contractor during the exploration period. Decisions of the JM[A]C are normally taken unanimously or by consensus, but in the event of a deadlock, the usual practice is that the Chairman has the casting vote. Although the JM[A]C's functions are supervisory in nature over certain matters under the PA, they are always without prejudice to the rights and obligations of the Contractor for the day-to-day management of petroleum operations. Thus, the scope of the JM[A]C's authority is normally quite limited, but will usually encompass:

(a) all work programs, budgets and other reports and proposals required under the PA to be submitted to the CA;

(b) progress of Contractor's work;

(c) terms of contracts with subcontractors, and their performance; and

(d) any problem arising in the conduct of petroleum operations.

The JM[A]C may also form technical subcommittees, which act as forums as well for both consultation and a conduit for transfer of technology and know how between the Contractor and the State or CA.

(6) Cost Recovery, Expenses and Production Shares - Assuming that we are dealing with the majority-preferred, "state-of-the-art" MC variant - slidingscale production sharing ${ }^{38}$ - this section of the MC will: (a) subject to the

\footnotetext{
38. Whilo, as sald, thls anabyals ls based on the sliding-scale PSC MC variant, one may also vary the baste MC format to produce other standard arrangements, Including: License or Concession with tax and royalty; Risk-Service Contract or Service Contract. Much of the easentlal elements of the MC discussed herein will be the same, with the principle changes belng in the mwo and fiseal provislons.
} 
Accounting Procedure and the auditing provisions of the MC, provide for Contractor's cost recovery, which, as earlier explained, may be bid and negotiated within the acceptable ranges or levels of percentages of cost oil established in the Regs; (b) detail the manner in which operating, capital and pre-commercial production costs and expenses shall be allocated and recovered against cost oil ; and (c) set out - in proportions to be bid and negotiated within the acceptable ranges established in the Regs - the shares of profit oil due to the State or CA and the Contractor, based on average daily production over a contract month from the Contract Area ${ }^{39}$. Similar such provision will also be made for natural gas in a modern contractual framework ${ }^{00}$.

(7) Taxes and Duties - Once again, under a sliding-scale PSC MC - where Contract-or's taxes are deemed-paid within its progressive (or regressive) production shares - the $\mathrm{CA}$, on behalf of the State, will undertake to hold and keep Contractor harmless from all present and future host State taxes and duties otherwise generally applicable to petroleum operations ${ }^{11}$, except

\footnotetext{
33. Aleo, a provblon will appaar in this articlo to the effuct that prior to the commencement of commerelal production, the CA and the Contractor will agres on a liting procedure for their res pective production shares on a regular bask. Soms Mes will dotall the essontlal provisions of such a liting procedure whilo others will go further and attach a pro forma liting acreemont as an appondk.

40. As cartiar montioned in Soction A. abovo, in hoat States which are known or oxpected to be partleulariy gae-prons, both the PL and tho MC will contaln a soparato articio provlding for spacial incentives and priortices for Contractor to dovelop such matural gas. Ploeses seo foothot 21., above, for greator dotall.

1. It is intereating to now here that, athar several years of uncertainty undar an eusentially unworkable lleanaing and

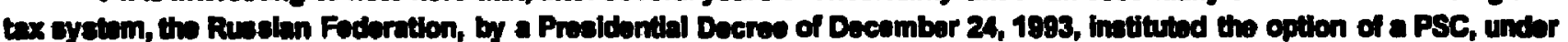
which the production sharing arrengomont negotiatad between the parties will bo in liou of all taxes othorwbe pryable on petrobum oporattons.
} 
for those

specifical

ly named

a $n$ d excluded

in this

article of

t h e

M C . ${ }^{42}$

$\mathbf{F} \mathbf{r}$

purposes

of the

foreign

tax credit

f $0 \mathrm{r}$

certain
A simplified example of the Pac methodology calculation on a "Coutractor's Tax Pald" basis might be:

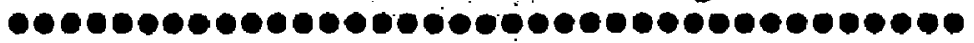
Arane

1. Cont Oil agread to be 30s of Grogs Froduction; and

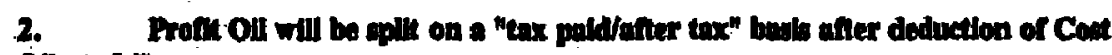
O4, is Ellows:

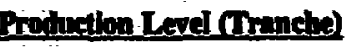

Sence

ENP

Sine

Confector

$0-50,000$

50,001 - 100,000

$100,001-150,000$

$150,000-200,000$

zopentand op

65. 35

675325

70 30

7.5. 27.5

$75 \quad 23$

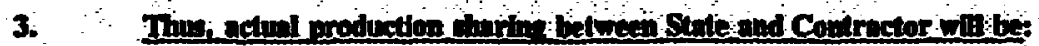

onte

Contextor

A. Promoulonetos)

(1)000,000 (60530,000) 32,500

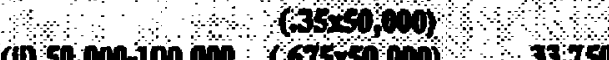

(i) s0,000-100,000 60750,000$), 39750$

(60,0,0)

(ii) $100,000,150,000(70 \%-0,00)$

35,000

(3.5.0.0.0)

से

(t) 1 bo, $10,20,00,(2,2,1,0)$

6, 18

rorris

10960

B, Con or $(30,2=0,010)$

$\rightarrow+\infty$
17,30

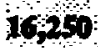

16;on

$\sin$

ses.12

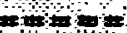

75,00

IOC Contractors, it is desirable both to: (a) reaffirm Contractor's liability to generally applicable laws of the host State which impose taxes on or measured by income or profits; and (b) confirm that the CA's share of petroleum from the Contract Area, taken pursuant to the applicable

4. These excluslons will normally bo: taxes on income of subcontractors; income tux on Contractor's employees and thoes of lis subcontractors; duties and taxes on locally purchaeed goods and commorcial zorvices providod by public outhoritica; and texes on tobaceo and alcohot. 
provisions of a PA, includes an amount equal in value to all of the income and profit taxes due by Contractor under its $\mathbf{P A}^{43}$.

(8) Fees and Bonuses - This article will, consistent with requirements in the Regs, set out the times of payment and the amounts of any: land rentals or contract administration fees; signature bonus; declaration of commercial discovery bonus; initial and additional production bonuses - set at incremental, sustained production levels - all as may be bid and negotiated in the PA.

(9) Protection of the Environment - Complementary to Contractor's general obligation under the PL to carry out petroleum operations in accordance with good international oilfield practice - such having evolved today to being necessarily duly protective of the environment and safety - an up-to-date MC will now require Contractor to take, in particular, all necessary steps to:

(a) ensure that petroleum operations avoid, or if unavoidable, result in minimal ecological damage or destruction;

(b) control the flow and prevent the escape or the avoidable waste of petroleum produced in the Contract Area;

(c) prevent damage or waste to petroleum-bearing strata; and

(d) prevent damage to land, fresh water supplies/aquifers, trees, crops, other plant, marine or animal life, buildings or other structures.

If Contractor fails to comply with any of the above requirements and pollution results, the $\mathrm{MC}$ will require it, on an emergency basis, to control,

\footnotetext{
43. Including a mechaniem by which the CA will actually pay and discharge such tuxes on bohall of Contrector, providing it with oficicial recolptes as ovidonce.
} 
clean up and repair all such damage to the maximum extent feasible, using the best available technology for the purpose. If such pollution results from Contractor's negligence, established practice is to deny it the right to include the costs of such remedial procedures in its cost recoverable expenses under the PA. In addition, the MC will require Contractor to take all steps at termination of the PA to ensure restoration of the environment where petroleum operations were carried out"

(10) Supply of Domestic Market: Emergency Requisition - Reafirming the premise that the State owns all of its petroleum resources, subject to the Contractor's rights to an agreed portion thereof under a PA, the MC should provide both for the CA's right to: (a) require Contractor to sell some portion of its production share to meet internal domestic demand; and (b) in case of grave national emergency, war or its imminent expectation, requisition all or part of petroleum production from the Contract Area, concurrently requiring Contractor to maximize same. This will be qualified in the case of (a), above, by a requirement of adequate advance notice to the Contractor ${ }^{15}$ of both required quantities of petroleum and duration of supply - in recognition of Contractor's likely external long-term commitments otherwise to sell or utilize its production share - and for both (a) and (b),

\footnotetext{
4. I b beat to requile Contractor to aubmil to the CA, for the conalderation and approval, an outilne secheme for mestoretien of the cporating emvironment.

45. Normal practice would be to glve a minimum of two (2) quarters' notice to Contrector before the Ca exarelaces lis purchase ifists andior this artelo.
} 
above, by the obligation of the CA to pay the Contractor for purchased or requisitioned petroleum in hard-currency, abroad and at the international price calculated pursuant to the applicable provisions in the PA.

(11) Training of Host State Personnel - Where the State chooses to allocate the responsibilities of both contract administration of the PA and technical interface thereunder to its NOC, if extant, it is best to require in the PA that Contractor shall train, in a planned, systematic and phased manner, NOC personnel in all aspects of petroleum operations. Such training will be at Contractor's cost and expense but will be allowable as approved costs for the purpose of cost recovery under the PA.

(12) Other Standard Provisions - Once again, circumstances will vary considerably from one MC or PA to another as to degree of detail and emphasis, but a complete MC will also always include articles addressing:

(a) Valuation of Petroleum;

(b) Title to Assets and Data;

(c) Payment and Currency;

(d) Accounts, Financial Reporting and Audit;

(e) Records, Inspection and Confidentiality;

(f) Force Majeure;

(g) Termination and Events of Default;

(h) Applicable Law and Stabilization;

(i) International Arbitration and Expert Determination; 


\section{(j) Notices; and}

(k) Effectiveness and Amendment.

Standard appendices to an MC, along with those already mentioned, will always include: a map and description of the Contract Area; and a standard form of Accounting Procedure, which incorporates principles and procedures of accounting generally in use in the international petroleum sector.

\section{v. Conclusion}

While the foregoing discussion on the escential elements of legislative frameworks used to foster development of the potential indigenous petroleum resources of host countries is intended to be reasonably comprehensive, it is by no means exhaustive. Within all of the essential elements of each basic component discussed above - PL, Regs \& MC(s) - there is always considerable room for myriad variations and innovation, depending very greatly on the degree of actual or percelved hydrocarbon endowment of the host State concerned. As always, this is the threshold determination which will necessarily dictate the choices then to be made on specific elements, terms, allowances and incentives - all within the basic parameters of the legislative norms recommended in this paper.

Although, as first said, this paper has sought both to clarify and explain the principles and rationale for each essential element of legal frameworks used to foster petroleum development - as a useful tool for Bank staff involved in PEPPs or other 
$-57-$

petroleum sector projects with legal reform or TA components - it is re-emphasized here that the actual drafting of such regimes is highly specialized and, in every case, must be done by experienced petroleum lawyers who are thoroughly familiar with petroleum E\&P laws and contractual arrangements. 


\section{TABLE OF BANK GROUP'S RELEVANT PETROLEUM SECTOR LOANS, CREDITS, INVESTMENTS AND LEGAL TA (EFFECTIVE AND PROPOSED) 1980 - 1994}

1. ARGENTINA: Petroleum Exploration and Development Project (INVEST. NO. 1114 AR) SIGNED: 12-29-1988

2. BANGLADESH: Petroleum Exploration Promotion Project (CREDIT NO. 1402 BP) SIGNED: 09-16-1983

3. BOLIVIA: (BERMEJO) Petroleum Exploration \& Development (INVEST. NO. 2608 BO) SIGNED: 08-06-1991

4. CONGO: Economic Recovery Credit (CREDIT NO. 2635 CG) SIGNED: 06-29-1994

5. EGYPT: Abu-Gharadig - Western Desert Petroleum Exploration Project (LOAN NO. 1928 EG) SIGNED: 01-13-1981

6. ETHOPIA: Petroleum Exploration Promotion and Geothermal Reconnaissance Project (CREDIT NO. 1386 ET) SIGNED: 09-16-1983

7. ETHIOPLA: Red Sea Offshore Petroleum Exploration (INVEST. NO. 1093 ET) SIGNED: 05-10-1989

8. GUINEA-BISSAU: Petroleum Exploration Promotion Project (CREDIT NO. 1095 GW) SIGNED: 01-15-1981

9. GUINEA-BISSAU: Anetibene Petroleum Exploration (CREDIT NO. 1334 GW) SIGNED: 03-24-1983

10. GUINEA-BISSAU: Petroleum Exploration Promotion Project (INVEST. NO. $1224 \mathrm{GW}$ ) SIGNED: 02-23-1990

11. GUINEA: Petroleum Exploration Promotion Project (CREDIT NO. 1208 GN) SIGNED: 11-24-1982 
12. GUINEA: Petroleum Exploration Promotion Project

(CREDIT NO. 1438 GN) SIGNED: 01-31-1984

13. HONDURAS: Petroleum Exploration Promotion Project (LOAN NO. 1861 HN) SIGNED: 06-23-1980

14. INDIA: Krishna - Godavari Petroleum Exploration Project (LOAN NO. 2205 IN) SIGNED: 12-23-1982

15. INDIA: Petroleum Exploration Program (INVEST. NO. 2783 IN) SIGNED: 07-22-1991

16. JAMAICA: Petroleum Exploration Project

(LOAN NO. 2017 JM) SIGNED: 09-21-1981

17. KAZAKHSTAN: Petroleum Legislation (TCP NO. 28505 KZ) SIGNED: 04-30-1992

18. KAZAKHSTAN: Petroleum Training (TCP NO. $28532 \mathrm{KZ}$ ) SIGNED: 04-30-1992

19. KENYA: Petroleum Exploration Promotion Project (LOAN NO. 2065 KE) SIGNED: 01-13-1982

20. KENYA: Petroleum Exploration Technical Assistance Project (CREDIT NO. 1675 KE) SIGNED: 07-11-1986

21. LIBERIA: Petroleum Exploration Promotion Project (LOAN NO. 1907 LR) SIGNED: 11-21-1980

22. MADAGASCAR: Petroleum Exploration Project (CREDIT NO. 1016 MG) SIGNED: 05-08-1980

23. MADAGASCAR: Tsimiroro Heavy Oil Exploration Project (CREDIT NO. 1298 MG) SIGNED: 12-03-1982

24. MAURITANIA: Petroleum Exploration Promotion Project (CREDIT NO. 1175 MR) SIGNED: 12-23-1981

25. MOROCCO: Petroleum Exploration Project (LOAN NO. SO18 MA) SIGNED: 05-19-1980

26. MOROCCO: Petroleum Exploration and Essouira Appraisal Project (LOAN NO. 2271 MA) SIGNED: 05-22-1983 
27. NEPAL: Petroleum Exploration Promotion Project (CREDIT NO. 1260 NP) SIGNED: 07-09-1982

28. NIGERIA: Oso Condensate Field Development Project (LOAN NO. 3317 NG) SIGNED: 04-24-1991

29. PAKISTAN: Petroleum Exploration Project

(LOAN NO. 2351 PK) SIGNED: 10-18-1983

30. PAKISTAN: Petroleum Resources Joint Venture Project (LOAN NO. 2553 PK) SIGNED: 06-26-1985

31. PANAMA: Planning and Petroleum Exploration Promotion Project (LOAN NO. 1954 PA) SIGNED: 04-23-1981

32. PAPUA NEW GUINEA: Petroleum Exploration Technical Assistance Project (CREDIT NO. 1279 PG) SIGNED: 11-05-1982

33. PHIIIPPINES: Petroleum Exploration Troject (LOAN NO. 2201 \& 2202 PH) SIGNED: 09-18-1982

34. POLAND: Energy Resource Development Project (LOAN NO. 3215 PL) SIGNED: 07-02-1990

35. PORTUGAL: Petroleum Exploration Project (LOAN NO. 2024 PT) SIGNED: 09-02-1981

36. ROMANIA: Petroleum Sector Rehabilitation Project (LOAN NO. 3723 RO) SIGNED: 06-01-1994

37. RUSSIAN FEDERATION: Petroleum Legislation (TCP NO. 28504 RU) SIGNED: 02-26-1992

38. RUSSIAN FEDERATION: Petroleum Critical Imports Project (LOAN NS. 3623 RU) SIGNED 08-12-1993

39. RUSSIAN FEDERATION: Petroleum Training (TCP NO. 28531 RU) SIGNED 04-30-1992

40. RUSSIAN FEDERATION: Petroleum Enterprise Reform (TCP NO. 28527 RU) SIGNED: 04-15-1992 
41. SENeGal: Petroleum Exploration Project (CREDIT NO. 1323 SN) SIGNED: 03-31-1983

42. SOMALIA: Petroleum Exploration Promotion Project (CREDIT NO. 1043 SO) SIGNED: 11-07-1980

43. TANZaNIA: Petroleum Exploration Project (CREDIT NO. 1199 TZ) SIGNED: 01-13-1982

44. TUNISIA: Petroleum Exploration Promotion Project (LOAN NO. 3023 TN) STGNED: 05-10-1989

45. TURKEY: Petroleum Exploration Project (LOAN NO. 1916 TR) SIGNED: 11-24-1980

46. UGANDA: Petroleum Exploration Promotion Project (CREDIT NO. 1561 UG) SIGNED: 05-30-1985

47. UZBBEKISTAN: Institution Building Technical Assistance Loan (LOAN NO. 3650 UZ) SIGNED: 10-22-1993

48. YEMEN: Petroleum Exploration Promotion Project (CREDIT NO. 1050 YE) SIGNED: 07-11-1980

49. YEMEN: Petroleum Eynloration Promotion Project (CREDIT NO. 1216 YE) SIGNED: 04-09-1982

50. ZAMBIA: Petroleum Exploration Promotion Project (LOAN NO. 2152 ZM) SIGNED: 06-14-1982 
PROPOSED PROJECTS

1. AZERBaIJAN: Petroleum Technical Assistance

2. DOMINICAN REPUBLIC: Petroleum Exploration Project

3. FUI: Petroleum Exploration Project

4. GUYANA: Offshore Petroleum Exploration Project

5. KAZAKHSTAN: Petroleum Technical Assistance Project

6. MADAGasCaR: Cap. St. Andre Petroleum Exploration Project

7. NIGERIA: Escravos Gas Flaring Reduction Project

8. PAPUA NEW GUINEA: Petroleum Exploration and Development Technical Proposed Project

9. PARAGUAY: Curupaity Block Petroleum Exploration Project

10. RUSSIAN FEDERATION: Sakhalin Island Petroleum Project Bid Evaluation Procedures

11. SENEGAL: Dome Tore Drilling and Petroleum Exploration Promotion Project

12. TURKMENISTAN: Institution Building/Technical Assistarice Project

13. TURKMeNISTAN: Oil \& Gas Sector Project

14. YEMEN: Petroleum and Geothermal Exploration Promotion Project 


\section{Policy Research Working Paper Series}

\begin{tabular}{|c|c|c|c|c|}
\hline & Title & Author & Date & $\begin{array}{l}\text { Contact } \\
\text { for paper }\end{array}$ \\
\hline WPS1397 & $\begin{array}{l}\text { Are Private Capital Flows to } \\
\text { Developing Countries Sustainable? }\end{array}$ & $\begin{array}{l}\text { Uri Dadush } \\
\text { Ashok Dhareshwar } \\
\text { Ron Johannes }\end{array}$ & December 1994 & $\begin{array}{l}\text { J. Queen } \\
33740\end{array}$ \\
\hline WPS1398 & The Cost of Air Pollution Abatement & $\begin{array}{l}\text { Raymond S. Hartman } \\
\text { David Wheeler } \\
\text { Manjula Singh }\end{array}$ & December 1994 & $\begin{array}{l}\text { E. Schaper } \\
33457\end{array}$ \\
\hline WPS1399 & $\begin{array}{l}\text { How Important to India's Poor is the } \\
\text { Uiban-Rural Composition of Growth? }\end{array}$ & $\begin{array}{l}\text { Martin Ravallion } \\
\text { Gaurav Datt }\end{array}$ & December 1994 & $\begin{array}{l}\text { P. Cook } \\
33902\end{array}$ \\
\hline WPS1400 & $\begin{array}{l}\text { Technical and Marketing Support } \\
\text { Systems lor Successful Small and } \\
\text { Medium-Size Enterprises in Four } \\
\text { Countries }\end{array}$ & $\begin{array}{l}\text { Brian Levy with } \\
\text { Albert Berry, Motoshige Itoh, } \\
\text { Linsu Kim, Jeffrey Nugent, } \\
\text { and Shujiro Urata }\end{array}$ & December 1994 & $\begin{array}{l}\text { D. Evans } \\
38526\end{array}$ \\
\hline WPS1401 & $\begin{array}{l}\text { Colombia's Small and Medium-Size } \\
\text { Exporters and Their Support Systems }\end{array}$ & $\begin{array}{l}\text { Albert Berny } \\
\text { Jose Escandon }\end{array}$ & December 1994 & $\begin{array}{l}\text { D. Evans } \\
38526\end{array}$ \\
\hline WPS1402 & $\begin{array}{l}\text { Indonesia's Small and Medium-Size } \\
\text { Exporters and Their Support Systems }\end{array}$ & $\begin{array}{l}\text { Albert Berry } \\
\text { Brian Levy }\end{array}$ & December 1994 & $\begin{array}{l}\text { D. Evans } \\
38526\end{array}$ \\
\hline WPS1403 & $\begin{array}{l}\text { Small and Medium-Size Enterprise } \\
\text { Support Policies in Japan }\end{array}$ & $\begin{array}{l}\text { Motoshige lioh } \\
\text { Shujiro Urata }\end{array}$ & December 1994 & $\begin{array}{l}\text { D. Evans } \\
38526\end{array}$ \\
\hline WPS1404 & $\begin{array}{l}\text { The Republic of Korea's Small and } \\
\text { Medium-Size Enterprises and Their } \\
\text { Support Systems }\end{array}$ & $\begin{array}{l}\text { Linsu Kim } \\
\text { Jeffrey B. Nugent }\end{array}$ & December 1994 & $\begin{array}{l}\text { D. Evans } \\
38526\end{array}$ \\
\hline WPS1405 & Growth and Poverty in Rural India & $\begin{array}{l}\text { Martin Ravallion } \\
\text { Gaurav Datt }\end{array}$ & January 1995 & $\begin{array}{l}\text { WDR } \\
31393\end{array}$ \\
\hline WPS1406 & $\begin{array}{l}\text { Structural Breaks and Long-Run } \\
\text { Trends in Commodity Prices }\end{array}$ & $\begin{array}{l}\text { Javier León } \\
\text { Raimundo Soto }\end{array}$ & January 1995 & $\begin{array}{l}\text { R. Luz } \\
31320\end{array}$ \\
\hline WPS1407 & $\begin{array}{l}\text { Pakistan's Agriculture Sector. } \\
\text { Is } 3 \text { to } 4 \text { Percent Annual Growth } \\
\text { Sustainable? }\end{array}$ & Rashid Faruqee & January 1995 & $\begin{array}{l}\text { F. Willie } \\
82262\end{array}$ \\
\hline WPS1408 & $\begin{array}{l}\text { Macroeconomic Management and } \\
\text { Intergovernmental Relations in } \\
\text { China }\end{array}$ & Jun Ma & January 1995 & $\begin{array}{l}\text { C. Jones } \\
37754\end{array}$ \\
\hline WPS1409 & $\begin{array}{l}\text { Restructuring Uganda's Debt: } \\
\text { The Commercial Debt Buy-Back } \\
\text { Operation }\end{array}$ & Kapil Kapoor & January 1995 & $\begin{array}{l}\text { E. Spano } \\
35538\end{array}$ \\
\hline WPS1410 & $\begin{array}{l}\text { Macroeconomic Effects of Terms- } \\
\text { of-Trade Shocks: The Case of Oil- }\end{array}$ & $\begin{array}{l}\text { Nikola Spatafora } \\
\text { Androw Warner }\end{array}$ & January 1995 & $\begin{array}{l}\text { J. Queen } \\
33740\end{array}$ \\
\hline
\end{tabular}

Exporting Countries 
Policy Research Working Paper Serles

Title

WPS1411 Income Inequality, Welfare, and Poverty: An Illustration Using Ukrainian Data

WPS1412 Foreign Technology Imports and Economic Growth in Developing Countries

WPS1413 Endogenous Distortions in Product and Labor Markets

WPS1414 The World Bank and Legal Technical Assistance: Initial Lessons

WPS1415 China's GDP in U.S. Dollars Based on Purchasing Power Parity

WPS1416 Informal Regulation of Industrial Pollution in Developing Countries: Evidence from Indonesia

WPS1417 Uncertainty and Global Warming: An Option-Pricing Approach to Policy

WPS141B The Impact of Labor Market Regulations

WPS1419 Industry Structure and Regulation

WPS1420 Legisłative Frameworks Used to Foster Petroleum Development
Author

Nanak Kakwani

Xiaoming Zhang

Heng-fu Zou

Martin Rama

Guido Tabellini

The World Bank

Legal Department

Ren Ruoen

Chen Kaj

Sheoli Pargal

David Wheeler

Andrea Baranzini

Marc Chesney

Jacques Morisset

Lyn Squire

Sethaput Suthiwart-

Narueput

Martin C. Stewart-Smith

William T. Onorato
January 1995

Date

Contact

for papor

G. Evans

85783

January 1995

C. Jones

37754

January 1995

S. Fallon

38009

January 1995

January 1995

February 1995

February 1995

C. Dell

85148

February 1995

G. Bayard

37460

February 1995

N. James

82758

February 1995
W. Onorato 81611 
